\title{
Benthic foraminiferal response to sedimentary disturbance in the Capbreton canyon (Bay of Biscay, NE Atlantic)
}

\author{
Duros Pauline ${ }^{1,3}$, Silva Jacinto Ricardo ${ }^{1}$, Dennielou Bernard ${ }^{1}$, Schmidt S. ${ }^{2}$, Martinez Lamas Ruth ${ }^{1}$, \\ Gautier Emeric ${ }^{1}$, Roubi Angelique ${ }^{1}$, Gayet Nicolas ${ }^{1}$
}

${ }^{1}$ IFREMER, Laboratoire Géodynamique et enregistrement Sédimentaire (LGS), BP70, 29280 Plouzané, France

${ }^{2}$ CNRS, OASU, EPOC, UMR 5805, University of Bordeaux, F-33615 Pessac Cedex, France

${ }^{3}$ FORAM, Foraminiferal Study Group, F-49140 Villevêque, France

\begin{abstract}
:
Living (Rose Bengal stained) and dead benthic foraminifera were investigated at 6 deep-sea sites sampled in the Capbreton canyon area (Bay of Biscay, France). Three sites were located along the canyon axis at $301 \mathrm{~m}, 983 \mathrm{~m}$ and $1478 \mathrm{~m}$ and 3 stations were positioned on adjacent terraces at $251 \mathrm{~m}$, $894 \mathrm{~m}$ and $1454 \mathrm{~m}$. Sedimentary features indicate that frequent sedimentary disturbances of different magnitudes occur along the Capbreton canyon axis and adjacent terraces. Such environmental conditions cause the presence of very particular benthic environments. Along the 6 studied sites, different foraminiferal responses to various sedimentary patterns are observed revealing the complexity of this canyon environment. Some sites (Gitan 3 (canyon axis), Gitan 5 (canyon axis) and Gitan 6 (terrace)) are characterized by moderate to low standing stocks and low diversity and are mainly dominated by pioneer taxa such as Fursenkoina brady, Reophax dentaliniformis and Technitella melo suggesting a recent response to turbidite deposits recorded at these sites. Others sites (Gitan 1 and Gitan 2) show extremely high standing stocks and are mainly dominated by the opportunistic Bolivina subaenariensis and Bulimina marginata. Such faunal characteristics belonging to a more advanced stage of ecosystem colonization indicates strongly food-enriched sediment but extremely unstable conditions. Moderate standing stocks and diverse assemblage composed of species such as Uvigerina mediterranea and $U$. peregrina has only been observed at the terrace site Gitan 4. More stable sedimentary conditions recorded at this terrace seem to be suitable to the development of a dense and diverse foraminiferal community. Numerous neretic allochtonous species were observed in the dead foraminiferal fauna. These allochthonous species mainly originate from shelf areas $(<60 \mathrm{~m})$.
\end{abstract}




\section{Highlights}

- Live benthic foraminifera were studied at 6 deep stations in the Capbreton Canyon. Benthic foraminifera were sampled along canyon axis and its adjacent terraces. The aim is to use foraminifera as bio-indicators of hydro-sedimentary processes.

Keywords : Benthic foraminifera, Capbreton canyon, Habitat disturbance, Turbidite, Submarine canyon 


\section{ACCEPTED MANUSCRIPT}

\section{Introduction}

Active submarine canyons are characterised by intensive sediment transport along the canyon axis. This transport is caused by different, hydro-sedimentary processes such as sediment gravity flows (i.e. turbidity currents) (Mulder et al., 2001), slumps (Hsu et al., 2008) or shelf water cascading events (Gaudin et al., 2006). Such processes provide large quantities of marine and reworked terrestrial organic matter that are concentrated in canyon sediments (e.g. Rowe et al., 1982; Soetaert and Heip, 1995; Vetter and Dayton, 1998). All these processes are triggered by climatic, meteorological or geologic events. Submarine canyons, where such events occur frequently, are characterised by a high degree of sediment instability (associates with transport and deposition of organic and inorganic matter) which constrain benthic community survival. For instance, in December 1999, a violent storm that affected the Atlantic coast of southern France, triggered a turbulent surge which deposited a huge turbidite in the Capbreton canyon (Bay of Biscay, NE Atlantic) (Mulder et al., 2001). After this sedimentary event, benthic foraminiferal fauna recovery was studied by Anschutz et al. (2002), Hess et al. (2005), Hess and Jorissen, (2009) and Bolliet et al. (2014) at sites from $400 \mathrm{~m}$ to $800 \mathrm{~m}$ depth (Figure 1). These studies documented the recolonization and subsequent recovery of the foraminiferal fauna, 4 months (Anschutz et al., 2002; Hess et al., 2005), 1.5 year (Hess et al., 2005; Hess and Jorissen, 2009) and 6 years (Bolliet et al., 2014) after the turbiditic event. Four months after this sedimentary disturbance, the living benthic foraminiferal fauna was almost entirely composed of Technitella melo in the coarse fraction $(>150 \mu \mathrm{m})$, a taxon that is usually very rare on the continental margin sediments. This species was accompanied in the 63-150 $\mu \mathrm{m}$ fractions by Cassidulina carinata, Fursenkoina bradyi, Bolivina subaenariensis and Bulimina marginata. This fauna represented the first stage of foraminiferal colonization after the turbidite deposition (Anschutz et al., 2002; Hess et al., 2005). One and a half year later, foraminiferal communities were dominated by other shallow infaunal species, Bolivina subaenariensis and Bulimina marginata that constitute the next phase of colonizers both in coarse and fine fractions. These species exhibited extremely high standing stocks (>6000 individuals per $100 \mathrm{~cm}^{2}$ ) (Hess et al., 2005; Hess and Jorissen, 2009). Six years after the turbidite deposit, benthic foraminiferal fauna still remained in an early stage of recolonization suggesting recurrent sediment instability (Bolliet et al., 2014). At distal sites, unaffected by recent re-sedimentation processes, foraminiferal fauna was diverse and specialized species occupied deep ecological niches within the sediment (Hess and Jorissen, 2009; Bolliet et al., 2014). 


\section{ACCEPTED MANUSCRIPT}

In the present study, we document living and dead benthic foraminifera from new sites (i.e. 300, 1000 and $1500 \mathrm{~m}$ ), along the Capbreton canyon axis and adjacent terraces (Figure 1). In addition to sedimentary features, the ecological features of living (Rose Bengal stained) benthic foraminifera (i.e. standing stock, diversity and vertical distribution) will allow us to determine which area is impacted by putative sedimentary disturbance (such as turbidite deposition), among the studied water depths. Foraminiferal response to potential sediment instability will be compared with previously documented studies in the Capbreton canyon (Anschultz et al., 2002; Hess et al., 2005; Hess and Jorissen, 2009; Bolliet et al., 2014; Figure 1, Table 1). The aim is to assess whether the foraminiferal response to sedimentary disturbance is the same in the entire Capbreton canyon area. In addition, dead foraminiferal fauna will be investigated at all sites in order to identify potential allochthonous individuals. Identification of such reworked foraminifera can give important clues about the downslope sedimentary dynamics and the source of sedimentary supplies (e.g. fluvial area, continental shelf, upper slope).

\section{Study area}

The Capbreton canyon is located in the southeastern Bay of Biscay (NE Atlantic) between $43^{\circ} 34^{\prime} \mathrm{N}$ and $43^{\circ} 42^{\prime} \mathrm{N}$. It deeply incises the Aquitaine continental slope and shelf. With a length of about $300 \mathrm{~km}$, Capbreton canyon is one of the longest canyons in Europe (Nesteroff et al., 1968). The canyon head is located only $250 \mathrm{~m}$ away from the French coastline at a water depth of $30 \mathrm{~m}$ and the canyon reaches up to $3000 \mathrm{~m}$ water depth at $133 \mathrm{~km}$ from the canyon head (Shepard and Dill, 1966). The canyon head was naturally disconnected from the Adour River in 1310 A.D., and in 1578 the river mouth was artificially relocated 15 kilometers south of the canyon head, preventing reconnection (Klingebiel and Legigan, 1978). Despite the disconnection from the Adour River, the canyon remains active. Hence, the Capbreton canyon is characterized by high organic matter input and substrate instability caused by bottom currents, small-scale environmental disturbances and re-sedimentation processes (Mulder et al., 2001; Anschutz et al., 2002; Gaudin et al., 2006). Sediment cores recovered in 2007 in the canyon axis, revealed high-frequency of small-scale gravity events (Mulder et al., 2012). Borcheray et al. (2014), based on sediment cores sampled in 2010, demonstrated a turbidite frequency of 1 per year. Moreover, according to Mulder et al. (2004), at least three massive turbidites have been deposited during the last century. One 


\section{ACCEPTED MANUSCRIPT}

major turbidite occurred in December 1999 and was induced by a turbulent surge triggered by the large Martin storm.

\section{Materiels and methods}

\section{1 - Sampling strategy}

The oceanographic cruise GITAN (Toucanne, 2015) was organized on board the " $R / V$ Pourquoi Pas?"'in August 2015. Six stations were sampled in the Capbreton canyon area with a multicorer in order to obtain cores with a relatively undisturbed sediment-water interface. Three of the stations were located in the canyon axis at $301 \mathrm{~m}$ (Gitan 1), $983 \mathrm{~m}$ (Gitan 3) and $1478 \mathrm{~m}$ (Gitan 5). The other three stations, Gitan 2 (251 m), Gitan 4 (894 m) and Gitan 6 $(1454 \mathrm{~m})$ were located on the terraces, $50 \mathrm{~m}, 156 \mathrm{~m}$ and $24 \mathrm{~m}$ above the canyon axis, respectively (Figure 1). At each site one core was used for foraminiferal analysis, two cores were devoted to sedimentological analysis and one core was dedicated to radionuclide measurements $\left({ }^{210} \mathrm{~Pb}\right)$.

\section{2 - Sedimentological analyses}

In order to appreciate downcore changes in lithology, the cores dedicated to sedimentological analyses were vertically split into two halves and photographed. At station Gitan 5, the two replicate cores available show different sedimentary records and are shown on Figure 2. Grain-size was measured on bulk sediment with a Malvern Laser Diffraction Mastersizer (type 3000). Since foraminifera can be the principal sedimentary components in the basal parts of turbidites, we decided not to apply carbonate dissolution prior to grain size measurements. Activities of ${ }^{210} \mathrm{~Pb}$ in excess $\left({ }^{210} \mathrm{~Pb}_{\mathrm{xs}}\right)$ were calculated as the difference of the measured activities of ${ }^{210} \mathrm{~Pb}$ and of its radioactive parent $\left({ }^{226} \mathrm{Ra}\right)$, both determined using a lowbackground, high efficiency, well-shaped $\gamma$ detector (see Bolliet et al., 2014 for more details). Supported ${ }^{210} \mathrm{~Pb}$, i.e. ${ }^{226} \mathrm{Ra}$, ranged between 18 and $28 \mathrm{mBq} \mathrm{g}{ }^{-1}$. Samples dominated by sand fraction were usually not measured as ${ }^{210} \mathrm{~Pb}_{\mathrm{xs}}$ is preferentially associated with the fine sediment fraction. The decay with time of ${ }^{210} \mathrm{~Pb}_{\mathrm{xs}}$ in the sediment column, according to its half-life of 22.3 years, is widely used to calculate sediment accumulation rates on decadal to 


\section{ACCEPTED MANUSCRIPT}

century timescale. Here we have applied the CF:CS method (constant flux and constant sedimentation, Robbins and Edgington, 1975) to estimate sediment accumulation rates, in $\mathrm{cm}$ per year, by plotting ${ }^{210} \mathrm{~Pb}_{\mathrm{xs}}$ against depth (see Schmidt et al., 2009 for details). Sedimentation patterns in the Capbreton canyon do not exactly fulfill the conditions of the CF:CS model. Calculated sediment must be considered as maximum rates, as they include also displaced sediments (that could be considered as instantaneous regarding the decadal timescale) in addition to the hemipalegic particulate deposition.

\section{3 - Foraminiferal fauna analyses}

For faunal analyses, entire sediment cores $\left(72.4 \mathrm{~cm}^{2}\right.$ surface area) were horizontally sliced into 11 intervals. Because of sampling artefact, the core was sliced in one interval of $1 \mathrm{~cm}$ between 0 and $1 \mathrm{~cm}$. Otherwise, the topmost of the core, where foraminiferal fauna is usually concentrated, was thinly sliced into 2 intervals of a half $\mathrm{cm}$ between 1 and $2 \mathrm{~cm}$. The core was sliced into 8 intervals of $1 \mathrm{~cm}$ down to $10 \mathrm{~cm}$. Sediments were stored in $500 \mathrm{cc}$ bottles, which were filled with $96 \%$ ethanol containing 2 g. $\mathrm{L}^{-1}$ Rose Bengal stain. All samples were gently shaken for several minutes in order to get a homogeneous mixture. In the laboratory, they were sieved through 63 and $150 \mu \mathrm{m}$ mesh screens, and the sieve residues were stored in $96 \%$ ethanol. All stained foraminifera belonging to the $>150 \mu \mathrm{m}$ fraction were sorted from wet samples, and stored in plummer slides. The small size fraction $(63-150 \mu \mathrm{m})$ was qualitatively inspected (Table 2).

The Rose Bengal staining technique (Walton, 1952; Bernhard, 1988) is routinely used to recognise foraminifera that were alive at the time of sampling. However, Rose Bengal may also stain the protoplasm of dead foraminifera, which may be relatively well preserved for a considerable period of time under the anoxic conditions that generally prevail deep in the sediment (Bernhard, 1988; Corliss and Emerson, 1990; Bernhard, 2000). In order to minimise the risk of counting dead foraminifera, we use the same strict staining criteria as those detailed in Fontanier et al. (2008). Non-transparent agglutinated and miliolid taxa were broken in order to inspect the test interior. Fragments of the very fragile arborescent agglutinating foraminiferal fragments (such as Hyperammina spp.) were not included, since it is impossible to determine how many individuals they represent. Because samples were stored in ethanol, many soft-shelled monothalamous foraminifera may have shrunk and may have become unrecognisable during picking. Thus, our counts will likely underestimate the soft- 


\section{ACCEPTED MANUSCRIPT}

walled foraminiferal group. Using a scanning electron microscope (SEM) at Ifremer Brest (FEI QUANTA 200 equipped with an Oxford Instrument Energy Dispersive Spectroscopy), we obtained digital photographs of foraminiferal individuals belonging to dominant species $(>5 \%)$. The total abundance of living foraminifera per core was determined by summing up the number of all specimens of all sediment intervals $(0-10 \mathrm{~cm})$. When describing the vertical distribution of foraminifera in the sediment, abundances are standardised for a $50 \mathrm{~cm}^{3}$ sediment volume. Diversity indices (species richness S, Shannon index H' and Evenness E index) were calculated with the software PAST (Palaeontological statistics http://folk.uio.no/ohammer/past/) using the following equations:

Species richness $\mathrm{S}$ : it is the number of taxa at each station.

Shannon H' index: $H^{\prime}=-\sum_{i=S}^{i=1}\left(\frac{n i}{N}\right) \times \ln \left(\frac{n i}{N}\right)$

where $n i$ is the number of individuals in the whole core for the species " $i$ ", $N$ is the total number of individuals for all intervals and $S$ the number of taxa. We distinguished between shallow and deep infaunal taxa. The former reach a maximum density in sediment layers just below the sediment-water interface, while the latter are most abundant in the slightly deeper suboxic and/or anoxic sediment layers.

Evenness E index: $E=\frac{e^{H^{\prime}}}{S}$

where $H^{\prime}$ is the Shannon index and $S$ the species richness. This index ranges from 0 to 1 .

After picking out the stained fauna, the sample residues were dried $\left(55^{\circ} \mathrm{C}, 48 \mathrm{~h}\right)$. The dead assemblages of the $>150-\mu \mathrm{m}$ size fraction were studied in two sediment levels per sites according to their lithofacies. In the case of a turbidite deposit, the aim was to analyse a silty level, at the top of the core and a sandy level at the bottom of the turbidite to identify putative allochthonous foraminiferal tests. As suggested by Murray (2006), we counted 250 to 300 individuals per sediment interval for each core. If necessary, samples were divided into subfractions using an Otto microsplitter. We also used scanning electron microscopy (SEM) to examine the major $(>5 \%)$ dead specimens.

\section{Results}

\section{1 - Sedimentological analyses}


Along the canyon axis, station Gitan 1 (301 m) exhibits two sedimentary units, S1 and S2, separated by an erosive contact (Figure 2). The topmost unit S1 is $15 \mathrm{~cm}$ thick. It is a finingupward sequence grading from coarse sands $(500-600 \mu \mathrm{m})$ to silty clays $(\sim 10 \mu \mathrm{m})$. Sediment unit $\mathrm{S} 2$ is a silty clay sequence (Figure 2). ${ }^{210} \mathrm{~Pb}_{\mathrm{xs}}$ activities are measured in the muddy layer $(0-8 \mathrm{~cm})$. Data are rather constant between 0 and $5 \mathrm{~cm}$ and then, show a slight decrease (Figure 2). Station Gitan $3(983 \mathrm{~m})$ shows a single sedimentary unit of $21 \mathrm{~cm}$ thickness (Figure 2). Grain size observed at Gitan 3 grades up from fine sands (200 $\mu \mathrm{m})$ to silty clays. ${ }^{210} \mathrm{~Pb}_{\mathrm{xs}}$ activities are rather constant between 0 and $8 \mathrm{~cm}$, followed by a sharp decrease in the layer $8-9 \mathrm{~cm}$, at the topmost of the sandy layer due to dilution by sand (low in ${ }^{210} \mathrm{~Pb}_{\mathrm{xs}}$ ) (Figure 2). Gitan 5 (1) (1478 m) exhibits one sedimentary unit of $12 \mathrm{~cm}$ thick which grades up from medium sands to silty clays. ${ }^{210} \mathrm{~Pb}_{\mathrm{xs}}$ activities in the topmost $5 \mathrm{~cm}$ silty-clay sediment of Gitan 5 (1) are almost constant (around $75 \mathrm{mBq} \mathrm{g}$; ; Figure 2) and lower than surface ${ }^{210} \mathrm{~Pb}_{\mathrm{xs}}$. of Gitan $6\left(101 \mathrm{mBq} \mathrm{g}^{-1}\right)$. Gitan 5 (2) (1478 m) shows seven sedimentary units (S1 to S7, Figure 2). The topmost sequence $\mathrm{S} 1$ is $3 \mathrm{~cm}$ thick. This unit exhibits a grain size which grades up from fine sands to silty clays. The sedimentary unit S2 is a fining-up sequence of $6 \mathrm{~cm}$ thick which obliquely erodes all sequences from S3 to S7. Grain size observed at the sequence S2 grades up from very fine sands to very coarse sands with gravels $(>2 \mathrm{~mm})$, large $(0.5-1 \mathrm{~cm})$ shelly fragments and dead gastropods (length 1-6 cm) (Figure 2). Sediment units S3 to S6 are fining-upward sequences from very fine sands to clayey silts. Sequence S7 is a silty clay unit with probably its base missing due to insufficient coring depth.

On adjacent terraces, stations Gitan $2(251 \mathrm{~m})$ and Gitan $4(894 \mathrm{~m})$ exhibit an homogeneous sediment composed of silty clays ( $D_{50}$ values close to $10 \mu \mathrm{m}$ at Gitan 2 and $7 \mu \mathrm{m}$ at Gitan 4, Figure 3). At Gitan $2,{ }^{210} \mathrm{~Pb}_{\mathrm{xs}}$ values exhibit only a slight decrease with depth, from $186 \mathrm{mBq} \mathrm{g}^{-1}$ in surface to $160 \mathrm{mBq} \mathrm{g}^{-1}$ at $50 \mathrm{~cm}$ (Figure 3). At Gitan $4,{ }^{210} \mathrm{~Pb}_{\mathrm{xs}}$ activities decrease regularly down-core. Station Gitan $6(1454 \mathrm{~m})$ shows at least 12 sedimentary units (sequences S1 to S12, Figure 3). For each sequence, grain size grades up from very fine sands $(86 \mu \mathrm{m})$ to clayey silts $(7 \mu \mathrm{m})$. The base of sequence S12 is missing due to insufficient coring depth. Superposed to the classical exponential decrease down to $50 \mathrm{~cm}$, ${ }^{210} \mathrm{~Pb}_{\mathrm{xs}}$ profile shows interbedded layers of low ${ }^{210} \mathrm{~Pb}_{\mathrm{xs}}$ and probably older sediment (Figure 3 ).

\section{2 - Living foraminiferal data (>150 $\mu$ m size fraction)}

\subsubsection{Standing stocks}




\section{ACCEPTED MANUSCRIPT}

Each terrace site exhibits higher foraminiferal standing stocks than adjacent stations situated along the canyon axis (Figure 4, Table 2). Very high standing stocks are recorded at the two shallowest sites. Gitan $1(301 \mathrm{~m})$, located along the canyon axis shows 6548 individuals per $100 \mathrm{~cm}^{2}$ and Gitan $2(251 \mathrm{~m})$, from adjacent terrace exhibits three times more individuals with 21490 ind./ $100 \mathrm{~cm}^{2}$ (Figure 4, Table 2). Gitan 3 (983 m), from the canyon axis exhibits 564 ind./ $100 \mathrm{~cm}^{2}$ and Gitan $4(894 \mathrm{~m})$, located on the terrace shows twice more specimens with 1046 ind./ $100 \mathrm{~cm}^{2}$. The lowest standing stock is observed at the deepest canyon station Gitan $5(1478 \mathrm{~m})$ with 242 ind./ $100 \mathrm{~cm}^{2}$. The adjacent terrace Gitan 6 (1454 m) shows a higher value with 1090 ind./ $100 \mathrm{~cm}^{2}$. To summarize, standing stocks decrease downstream, but are always higher on the terraces than in the adjacent canyon axis.

\subsubsection{Diversity}

Along the canyon axis, species richness (S) decreases with water depth from 44 at station Gitan $1(301 \mathrm{~m})$ to 13 at station Gitan $5(1478 \mathrm{~m})$ (Figure 4, Table 2). The Shannon index (H') ranges from 2.14 (Gitan 3, $983 \mathrm{~m}$ ) to 1.66 (Gitan 5, $1478 \mathrm{~m}$ ) and the Evenness index (E) varies from 0.41 (Gitan 5, $1478 \mathrm{~m}$ ) and 0.14 (Gitan 1, $301 \mathrm{~m}$ ), both without a bathymetric trend (Figure 4, Table 2). On adjacent terraces, species richness (S), the Shannon index (H') and the Evenness index (E) do not show any relationships with water depths. S values range from 47 at station Gitan $4(894 \mathrm{~m})$ to 12 at station Gitan 6 (1454 m) (Figure 4, Table 2). H' and E show maximum values at station Gitan 4 (894 m) (2.77 and 0.34, respectively). The lowest $\mathrm{H}^{\prime}$ and $\mathrm{E}$ values are recorded at the shallowest site Gitan 2 (251 m) (0.95 and 0.07, respectively) (Figure 4, Table 2).

\subsubsection{Faunal composition and vertical distribution along the canyon axis}

At station Gitan $1(301 \mathrm{~m})$, living foraminiferal fauna is dominated by Bolivina subaenariensis (39\%, 2564 individuals per $\left.100 \mathrm{~cm}^{2}\right)$, Bulimina marginata (26 \%, 1695 ind./ $\left.100 \mathrm{~cm}^{2}\right)$ and Leptohalysis scottii (15\%, 972 ind./ $100 \mathrm{~cm}^{2}$ ) (Figure 5; Figure 6A). Bolivina subaenariensis and Bulimina marginata exhibit a density maximum between 1 and $1.5 \mathrm{~cm}$ (Figure 6B). Leptohalysis scottii occupies an intermediate infaunal microhabitat, with a clear density maximum between 2 and $3 \mathrm{~cm}$ (Figure 6B). Fursenkoina bradyi (30 \%, 168 ind./ 100

$\mathrm{cm}^{2}$ ), Bolivina subaenariensis (20\%, 109 ind./ $\left.100 \mathrm{~cm}^{2}\right)$ Reophax dentaliniformis (16\%, 88 ind./ $\left.100 \mathrm{~cm}^{2}\right)$ and Technitella melo $\left(12 \%, 50\right.$ ind./ $\left.100 \mathrm{~cm}^{2}\right)$ are the dominant taxa at station Gitan 3 (983 m) (Figure 5; Figure 6C). Both species T. melo and R. dentaliniformis show a clear surface maximum (i.e. 0-1.5 cm, Figure 6D). Bolivina subaenariensis exhibits a 


\section{ACCEPTED MANUSCRIPT}

density maximum between 1 and $1.5 \mathrm{~cm}$. Fursenkoina bradyi occurs in an intermediate infaunal microhabitat with a density maximum between 1.5 and $2 \mathrm{~cm}$ (Figure 6D). Fursenkoina bradyi (41 \%, 98 ind./ $100 \mathrm{~cm}^{2}$ ), Reophax dentaliniformis (30\%, 72 ind./ 100 $\left.\mathrm{cm}^{2}\right)$, Haplophragmoides bradyi $\left(9 \%, 21\right.$ ind./ $\left.100 \mathrm{~cm}^{2}\right)$ and Uvigerina peregrina $(7 \%, 17$ ind./ $100 \mathrm{~cm}^{2}$ ) are the main species at the deepest station Gitan $5(1478 \mathrm{~m})$ (Figure 6E). Reophax dentaliniformis, Haplophragmoides bradyi and Uvigerina peregrina show a clear surface maximum $(<2 \mathrm{~cm}$ ) (Figure 6F). Fursenkoina bradyi shows a density maximum between 1 and $1.5 \mathrm{~cm}$ (Figure 6F).

\subsubsection{Faunal composition and vertical distribution on adjacent terraces}

Bolivina subaenariensis strongly dominates the foraminiferal fauna at the shallowest station Gitan $2(251 \mathrm{~m})$ with $78 \%$ (16 704 ind./ $100 \mathrm{~cm}^{2}$ ) (Figure 7A). Valvulineria bradyana and Bulimina marginata are subsidiary species with $8 \%$ (1640 ind./ $\left.100 \mathrm{~cm}^{2}\right)$ and $5 \%(1133$ ind./ $100 \mathrm{~cm}^{2}$ ), respectively (Figure 7A). These three species occupy a shallow infaunal microhabitat $(<2 \mathrm{~cm})$ (Figure 7B). Station Gitan $4(894 \mathrm{~m})$ shows 6 main species $(>5 \%)$, Uvigerina mediterranea $\left(27 \%, 278\right.$ ind./ $\left.100 \mathrm{~cm}^{2}\right)$, Uvigerina peregrina $(11 \%, 109$ ind./ $\left.100 \mathrm{~cm}^{2}\right)$, Melonis barleeanus (10\%, 101 ind./ $\left.100 \mathrm{~cm}^{2}\right)$, Bolivina alata (9\%, 90 ind./ 100 $\left.\mathrm{cm}^{2}\right)$, Siphogenerina columellaris $\left(6 \%, 61\right.$ ind./100 $\left.\mathrm{cm}^{2}\right)$ and Reophax scorpiurus $(5 \%, 55$ ind./ $100 \mathrm{~cm}^{2}$ ) (Figure 7C). Uvigerina mediterranea, Uvigerina peregrina and Reophax scorpiurus occur in a shallow faunal microhabitat with a density maximum between 1 and 1.5 cm (Figure 7D). Melonis barleeanus, Bolivina alata and Siphogenerina columellaris occupy an intermediate infaunal microhabitat with a density peak in the 1-3 cm interval (Figure 7D). Fursenkoina bradyi (66 \%, 722 ind./ $\left.100 \mathrm{~cm}^{2}\right)$, Haplophragmoides bradyi (22\%, 238 ind./ $\left.100 \mathrm{~cm}^{2}\right)$ and Chilostomella oolina $\left(5 \%, 57\right.$ ind./ $\left.100 \mathrm{~cm}^{2}\right)$ are dominant at station Gitan 6 (1454 m) (Figure 7E). Fursenkoina bradyi shows a density maximum between 1 and $2 \mathrm{~cm}$ (Figure 7F). Haplophragmoides bradyi does not exhibit a clear microhabitat preference. This species shows a bimodal distribution with a first maximum abundance between 1-1.5 cm and a second density peak between 2 and $3 \mathrm{~cm}$ (Figure 7F).

\section{3 - Qualitative observations of the living fauna in the 63-150 $4 \mathrm{~m}$ size fraction}

The surficial sediments $(0-1 \mathrm{~cm})$ at all sites were qualitatively inspected for smaller $(63-$ $150 \mu \mathrm{m}$ ) foraminifera. Main species observed are indicated in the Table 2. The species Bolivina subaenariensis is mainly dominant in the fine fraction of stations Gitan 1, Gitan 2 


\section{ACCEPTED MANUSCRIPT}

and Gitan 3. Others sites exhibit only few smaller individuals. Some individuals of Reophax scorpiurus, $R$. dentaliniformis and Fursenkoina bradyi are observed at Gitan 4, Gitan 5 and Gitan 6, respectively (Table 2).

\section{4 - Dead foraminiferal data (> $150 \mu$ m size fraction)}

4.4.1. Main species (> 5\%) along the canyon axis

Planorbulina mediterranensis (24\%), Elphidium spp. (22\%), Bolivina subaenariensis (13\%), Bulimina marginata (11\%), Cibicides lobatulus (9\%) and Cassidulina carinata (5\%) are the main species in the $2-3 \mathrm{~cm}$ level at station Gitan $1(301 \mathrm{~m})$. The two species Planorbulina mediterranensis and Cibicides lobatulus are also dominant in the 9-10 $\mathrm{cm}$ level with $71 \%$ and $6 \%$, respectively (Figure 8). At station Gitan $3(983 \mathrm{~m})$, Fursenkoina bradyi represents $32 \%$ of the dead assemblages in the $2-3 \mathrm{~cm}$ level. Cassidulina carinata (12\%), Planorbulina mediterranensis (8\%), Cibicides lobatulus (8\%), Bolivina subaenariensis (7.5 $\%$ ) and Elphidium spp. (5\%) are other dominant species (Figure 8). In the 9-10 cm level of site Gitan 3, Planorbulina mediterranensis is the main species with $38 \%$. Planorbulinella larvata (9\%), Labrospira jeffreysi (9\%) and Chilostomella oolina (8\%) are subsidiary species (Figure 8). At the deepest station Gitan 5 (1478 m), Fursenkoina bradyi is the main species of the $2-3 \mathrm{~cm}$ level but with only 4 individuals per $100 \mathrm{~cm}^{2}$ (Figure 8 ). In the $9-10 \mathrm{~cm}$ level of site Gitan 5, Quinqueloculina sp. 1 (33\%), Ammonia beccarii (19\%), Cibicides lobatulus (12\%), Bolivina subaenariensis (8\%), Elphidium spp. (7 \%) and Bulimina marginata (7\%) are the main species (Figure 8).

\subsubsection{Main species (> 5\%) on adjacent terraces}

At the shallowest site Gitan 2 (251 m), Bolivina subaenariensis and Bulimina marginata are the main species in the $2-3 \mathrm{~cm}$ level with $89 \%$ and $6 \%$, respectively (Figure 9). Bolivina subaenariensis is the only dominant species in the $9-10 \mathrm{~cm}$ level with $85 \%$ (Figure 9). At station Gitan 4 (894 m), Cassidulina carinata (29\%), Cibicides lobatulus (14\%), Bulimina marginata (11\%), Gavelinopsis translucens (5\%) and Textularia sagittula (5\%) are the main taxa in the 2-3 cm level (Figure 9). Cassidulina carinata, Cibicides lobatulus and Bulimina marginata are also dominant in the 9-10 cm level with relative abundances of $27 \%$, $18 \%$, and $14 \%$, respectively (Figure 9). In the 3-4 cm level of site Gitan 6 (1454 m), Fursenkoina bradyi represents $80 \%$ of the dead assemblages (Figure 9). In the 7-8 cm level, 


\section{ACCEPTED MANUSCRIPT}

Planorbulina mediterranensis, Fursenkoina bradyi and Haplophragmoides bradyi are the three main species with $34.5 \%, 28 \%$ and $7.5 \%$, respectively (Figure 9).

\section{Discussion}

\section{1 - Sedimentary features}

All cores sampled along the canyon axis (stations Gitan $1(301 \mathrm{~m}), 3(983 \mathrm{~m})$ and 5 $(1478 \mathrm{~m})$ ) exhibit at least one fining-upward sequence grading from sand (medium or fine) to fine silt, interpreted as fine-grained turbidites (Bouma, 1962; Stow and Shanmugam, 1980). At station Gitan 5, the coarse fraction of the topmost unit (medium sand) is also composed of gravel $(>2 \mathrm{~mm})$, large shell fragments $(1 \mathrm{~cm})$ and gastropods $(1-6 \mathrm{~cm})$ indicative of turbidity currents able to mobilise very coarse particles.

The terraces Gitan $2(251 \mathrm{~m})$ and $4(894 \mathrm{~m})$, located $50 \mathrm{~m}$ and $156 \mathrm{~m}$ above the canyon axis, respectively, exhibit homogeneous silty-clay. As observed by Brocheray et al. (2014), it seems that both sites receive only gently settling fine particle (around $10 \mu \mathrm{m}$ ), typical of the upper part of the suspension cloud of turbidity currents, which is dispersed over a larger surface than the lower coarse-grained part. At Gitan $2,{ }^{210} \mathrm{~Pb}_{\mathrm{xs}}$ activities show only a slight decrease with depth (Figure 4). This could be explained by an extremely high sediment fluxes (maximum accumulation rate $>15 \mathrm{~cm}$ year ${ }^{-1}$ ) resulting from continuous inputs of organic and inorganic sediment particles. At the highest terrace Gitan 4 (156 m above the canyon axis), no peculiar sedimentary feature is observed and ${ }^{210} \mathrm{~Pb}$ activities decrease regularly down-core. A maximum sedimentation rate of $0.82 \mathrm{~cm}$ year ${ }^{-1}$ has been derived from ${ }^{210} \mathrm{~Pb}_{\mathrm{xs}}$ profile which is still high compared to hemipelagic sedimentation outside the Capbreton canyon. In fact, Schmidt et al. (2009) recorded present-day sedimentation rates of 0.05 to $0.2 \mathrm{~cm}$ year $^{-1}$ on the Landes Plateau, at equivalent water depths. Therefore, both terraces Gitan 2 and Gitan 4 seem act as depocenters for fine-grained particles. This is consistent with the study of Gaudin et al. (2006) in which the terraces are interpreted as primary sedimentary depocenters in the Capbreton canyon. The deepest terrace Gitan 6, located only $24 \mathrm{~m}$ above the canyon axis, shows successions of twelve sedimentary units, graded from very fine sands to fine silts interpreted as fine-grained turbidites. At Gitan 6, a maximum sedimentation rate of $1.8 \mathrm{~cm}$ year ${ }^{-1}$ has been derived from ${ }^{210} \mathrm{~Pb}_{\mathrm{xs}}$ profile which is in correspondence to an estimate frequency of 1 turbidite every 3 years (Figure 3 ). This is consistent with the work of Brocheray et al. (2014) that demonstrated that fine-grained turbidites are preferentially 


\section{ACCEPTED MANUSCRIPT}

recorded on the shallower terraces near the Capbreton canyon axis. According to ${ }^{210} \mathrm{~Pb}$ dating, the sediment unit S4 could correspond to the 1999 turbidite triggered by the Martin storm (Figure 3).

\section{2 - Living benthic foraminiferal assemblages}

\subsubsection{Foraminiferal standing stocks}

All terraces sites exhibit higher standing stocks than adjacent canyon axis stations. For instance, the terrace site Gitan 6 shows four times more living individuals compared to the adjacent canyon site Gitan 5 (Table 1). Similar observations were made by Koho et al. (2007) in the Nazaré canyon area. These authors recorded the highest standing stocks in the canyon terrace stations with at several sites ten times more living fauna than the stations in the adjacent canyon axis. In both canyons, environmental conditions are more stable on canyon terraces compared to canyon axes which results in the accumulation of fine-grained sediment and organic carbon. These preferential conditions seem responsible for higher foraminiferal standing stocks.

\subsubsection{Foraminiferal response to sedimentary disturbance}

Foraminiferal communities with low to moderate standing stocks $\left(<1100\right.$ ind./ $\left.100 \mathrm{~cm}^{2}\right)$, low diversity, and the dominance of species such as Fursenkoina bradyi, Reophax dentaliniformis and Technitella melo, are observed at the canyon axis sites Gitan $3(983 \mathrm{~m})$ and Gitan $5(1478 \mathrm{~m})$ and at the deepest terrace station Gitan 6 (1454 m, Table 1 and Figures 6 and 7). Such foraminiferal characteristics are very similar to those described by Anschutz et al. (2002) and Hess et al. (2005) at a site recovered 4 months after the turbidite deposition triggered by the Martin storm in 1999 (site OB10 K (647 m); Figure 1, Table 1). Fursenkoina bradyi and Technitella melo were documented by Hess et al. (2005) as opportunistic species, first recolonizers after the turbidite deposition. These species appear to thrive in organically enriched sediments and to quickly colonize habitats after sedimentary disturbance ( $\mathrm{r}$ strategist) (e.g. Koho et al., 2007; Bernhard, 1992). Reophax dentaliniformis was documented by Hess and Kuhnt (1996) as one of the first pioneers to recolonize the barren substrate after an ashfall layer deposit triggered by the 1991 eruption of Mt. Pinatubo. Moreover, Bolivina subaenariensis is a subsidiary species at Gitan 3 (Figure 6C). This species was documented by Hess et al. (2005) as a secondary colonizer after Technitella melo and Fursenkoina bradyi, in the Capbreton canyon after turbidite deposits. Then, to have an idea of the population dynamics and how the foraminiferal fauna will evolve, the smaller fraction $(63-150 \mu \mathrm{m})$, was 


\section{ACCEPTED MANUSCRIPT}

qualitatively inspected (Table 2). At Gitan 5 and Gitan 6, few individuals of Fursenkoina bradyi and Reophax dentaliniformis were observed. At Gitan 3, the fine fraction is mainly represented by juvenile Bolivina subaenariensis. Other species such as Fursenkoina bradyi or Technitella melo are almost absent in the smaller fraction. Therefore, this suggests an ongoing recovery process at Gitan 3, slightly more advanced than at Gitan 5 and 6 (Figure 10). Turbidite deposits recorded at the deeper sites could be more recent compared to Gitan 3. But, it seems that it is the repeated frequency of sedimentary disturbances recorded at Gitan 5 and 6 (i.e. record of several turbiditic events, Figures 3 and 4, and see section 5.1) which probably sustain foraminiferal fauna in an early stage of recolonization.

A foraminiferal fauna with an extremely high standing stock ( $>20000$ ind./ $100 \mathrm{~cm}^{2}$ ), a low diversity and high dominance of the secondary colonizer Bolivina subaenariensis is recorded at terrace site Gitan $2(251 \mathrm{~m})$. Similar faunal characteristics were observed by Hess et al. (2005) and Hess and Jorissen (2009) at two sites recovered at about $600 \mathrm{~m}$ depth, one and a half year after the turbidite deposition caused by the Martin storm (stations L (632 m) and $\mathrm{K}(646 \mathrm{~m})$; Figure 1, Table 1). Hence at station Gitan 2, where a very important accumulation of sediment particles where recorded (see section 5.1), foraminiferal fauna seems to be in a more advanced stage of colonization compared to sites Gitan 3, 5 and 6 (Figure 10).

The upper canyon site Gitan $1(301 \mathrm{~m})$ exhibits a lower standing stock ( 6550 ind./ $100 \mathrm{~cm}^{2}$ ), and a more diverse assemblage, dominated by Bolivina subaenariensis and Bulimina marginata, compared to Gitan 2 (Table 2, Figure 6A). Such foraminiferal characteristics are very similar to those described by Hess et al. (2005) and Hess and Jorissen (2009) at three sites recovered one and a half year after the 1999 turbidite deposit (i.e. Stations Z2 (400 m), Z1 (406 m) and S (786 m), Table 1 and Figure 1). Many ecological observations reported also Bulimina marginata in organic matter-enriched sediment (e.g. Langezaal et al., 2006; Duchemin et al., 2007, Fontanier et al., 2008). Leptohalysis scotti is also a subsidiary species (>5\%) at this canyon site (Figure 6A). Leptohalysis scotti was also described as an opportunistic species able to quickly reproduce in response to episodic input of organic matter (Goineau et al., 2011). This species was also documented as an early colonizer of the 1991 Mt. Pinatubo ashfall deposit (Hess and Kuhnt, 1996) and after a physical disturbance experiment (e.g. Ernst et al., 2002). At Gitan 1, this species occupies a rather deep microhabitat (2-3 cm, Figure 6B). As documented by Hess et al. (2005) and Hess 


\section{ACCEPTED MANUSCRIPT}

and Jorissen (2009), the more diverse assemblage dominated by Bolivina subaenariensis and Bulimina marginata with a lower standing stock and a more developed microhabitat compared to Gitan 2 can be interpreted as a second generation of colonizers. Foraminiferal fauna at Gitan 1 appears to represent a more advanced stage of ecosystem colonization compared to all other sites discussed above (Figure 10).

Compared to all other stations, the highest terrace site Gitan 4 (894 m, $156 \mathrm{~m}$ above the canyon axis) exhibits the highest diversity and a moderate standing stock (Table 1, Figure 4). Foraminiferal fauna is dominated by Uvigerina mediterranea and Uvigerina peregrina (Table 1, Figure 7C). No pioneer species is observed. These faunal characteristics are similar to those found in a terrace site described by Hess and Jorissen (2009) in the Capbreton canyon area at $664 \mathrm{~m}$ depth (i.e. station SCII-A, Figure 1, Table 1). Uvigerina spp. are generally described in rather well-oxygenated sediment enriched in labile organic matter (e.g. Fontanier et al., 2005; Duros et al., 2013). In addition, some species exhibit strictly intermediate infaunal microhabitat (e.g. Melonis barleeanus and Bolivina alata, Figure 7D). According to Hess and Jorissen (2009), the terrace site described in their study is not influenced by the sedimentary disturbance processes which seems also to be the case for Gitan 4, according to structureless silty-clay lithofacies. Hence, due to its higher location above the canyon axis $(156 \mathrm{~m})$, this terrace exhibits much quieter hydro-sedimentary processes than all other sites (e.g. no turbidite deposit). Such stable conditions appear to be suitable to the development of a dense and a diverse foraminiferal community (Figure 10).

\section{3 - Dead benthic foraminiferal assemblages}

As shown by our results and other works (Mulder et al., 2001; Gaudin et al., 2006; Brocheray et al., 2014), the Capbreton canyon is active and characterized by massive and frequent sediment transport and deposition. Because of their small size, benthic foraminiferal faunas can be easily transported by sedimentary processes (e.g. bottom nepheloid layers, sediment gravity flows) (Murray, 1991, 2006; de Stigter et al., 1999). An important question is whether these sedimentary processes induced any post-mortem transport and redeposition of foraminiferal tests from shallower depths. This can be estimated by the identification of reworked allochthonous foraminifera (e.g. from fluvial areas, continental shelf, upper slope). 


\section{ACCEPTED MANUSCRIPT}

In the present study, some species such as Elphidium spp., Planorbulina mediterranensis, Planorbulinella larvata, Cibicides lobatulus and Ammonia beccarii occur exclusively in the dead foraminiferal fauna (Figure 5; Figures 8 and 9). Elphidium spp. (E. crispum, E. granosum and E. williamsoni) are usually described in nearshore environments at water depths between 0 and $35 \mathrm{~m}$ (e.g. Sen Gupta, 1999). Planorbulina mediterranensis, Planorbulinella larvata and Cibicides lobatulus are epiphytic perforate species thriving in the inner shelf. For instance Planorbulina mediterranensis and Cibicides lobatulus have been documented living at depths of 15-30 m attached on seagrass (Posidonia) and algae (Sturrock and Murray, 1981; Vénec-Peyré and Le Calvez, 1988; Murray, 2006). Ammonia beccarii has been reported from the interdistributaries (i.e., inner shore environments) to shallow coastal sandy areas ( 0 to $\sim 60 \mathrm{~m}$ water depth) in the Bay of Biscay and within the Rhône deltaic system (e.g. Pascual et al., 2008; Goineau et al., 2011). It seems therefore that all these shallow water species, exclusively present in the dead fauna, have been transported into this area (e.g. gravity flows, by bottom currents, in suspension or attached to floating sea grass or algae). To estimate the contribution of allochthonous (neritic) transported foraminifera, we determined cumulative percentages of such species that occur exclusively in the dead fauna (Table 3).

\subsubsection{Allochthonous taxa transported to the Canyon sites}

At Gitan $1(301 \mathrm{~m})$ several allochthonous taxa were recorded, especially in the sandy 9-10 $\mathrm{cm}$ level, located at the bottom of the turbidite deposit (Figure 8, Table 3). All these reworked species (e.g. Elphidium spp., Planorbulina mediterranensis and Cibicides lobatulus) have been transported from neritic areas (water depths $<35 \mathrm{~m}$ ) to this upper canyon site by a turbidity current.

At the canyon site Gitan 3, the $2-3 \mathrm{~cm}$ sediment level, which corresponds to an hemipelagic silty facies, is mainly composed of autochthonous taxa $(75 \%)$. Cibicides lobatulus is the main allochthonous taxon. The sandy $9-10 \mathrm{~cm}$ level predominantly consists of the epiphytic Planorbulina mediterranensis species. Both allochthonous taxa have been carried along the canyon axis from inner shelf $(\sim 30-60 \mathrm{~m})$ by the gravity event recorded at this site.

The silty 2-3 cm level of the deepest canyon axis site Gitan $5(1478 \mathrm{~m})$ exhibits only few dead individuals (Figure 8, Table 3). In the 9-10 $\mathrm{cm}$ level, dead individuals are diluted into 


\section{ACCEPTED MANUSCRIPT}

high quantities of medium sands. This sediment level is mainly composed by allochthonous species. Quinqueloculina sp. 1 (cf. seminula) which is completely absent in the living fauna is the main species in the dead fauna. All dead individuals observed at this site are highly broken and damaged (Figure 5X). Several authors documented Quinqueloculina spp. as characteristic of sandy sediment in very shallow-water environment $(<60 \mathrm{~m})($ e.g. Ikeya, 1970; Cearreta, 1989; Donnici and Serandrei Barbero, 2002; Frezza and Carboni, 2009; Goineau et al., 2011). This taxon seems reworked from neritic areas. Moreover, this species is accompanied in the dead fauna by the inner shelf $(<60 \mathrm{~m})$ taxa Ammonia beccarii and Cibicides lobatulus (Table 3). It seems that all these species have been carried from nearshore areas to this deep site through a massive sediment transport. Therefore, allochthonous species recorded at this deepest site, mainly dominated by Quinqueloculina sp. and Ammonia beccarii are quite different than those observed at shallower sites Gitan 1 and 3 where the epiphytic Planorbulina mediterranensis is the main neritic taxon. This may suggest a different source for the sediment transported by the turbidity currents.

Along the canyon axis, there is no substantial evidence of an effective downslope transport originating from upper canyon sites, towards deeper canyon sites. For instance, only few individuals of dead Bolivina subaenariensis $\left(<10\right.$ ind. $\left./ 100 \mathrm{~cm}^{2}\right)$ are recorded at the deepest Gitan 5 where this species is absent in the living fauna suggesting a possible downslope transport of some dead individuals from upper canyon sites (i.e. Gitan 1) where this taxon is dominant. Therefore, transport of tests seems mainly carried from inner continental shelf to the Capbreton canyon axis. Along the inactive nearby Cap-Ferret canyon axis, Duros et al. (2014) observed the opposite pattern. No substantial transport of shells $>150 \mu \mathrm{m}$ from the inner continental shelf to the Cap-Ferret Canyon axis was observed. However, transport of tests from outer shelf or upper canyon axis towards deeper sites mainly occurred, triggered by suspension/resuspension events and not by turbidity currents.

\subsubsection{Allochthonous taxa transported to terrace sites}

On the terrace Gitan $2(251 \mathrm{~m})$, both levels analyzed (i.e. $2-3 \mathrm{~cm}$ and 9-10 $\mathrm{cm}$ ) are composed of homogeneous silty-clay and mainly contain autochthonous species (Figure 9). The high abundance of dead individuals ( $>7000$ ind. $/ 100 \mathrm{~cm}^{2}$ ) seems indicated that several generations of this early colonizer have been succeeded. Diluted in the high abundance of dead Bolivina subaenariensis, some individuals $\left(256\right.$ ind./100 $\left.\mathrm{cm}^{2}\right)$ ) of the shallow-water 


\section{ACCEPTED MANUSCRIPT}

species Planorbulina mediterranea are recorded in the 9-10 $\mathrm{cm}$ level. This indicates that transports of reworked sediment from inner shelf may occur.

At Gitan $4(894 \mathrm{~m})$, both studied sediment levels $(2-3 \mathrm{~cm}$ and 9-10 $\mathrm{cm})$ are composed of homogeneous silty-clay and exhibit similar dominant species. The composition of the dead foraminiferal assemblage shows important differences with the living fauna found at the same site. Dead fauna is mainly dominated by Cassidulina carinata, Cibicides lobatulus and Bulimina marginata. The epiphytic taxon Cibicides lobatulus usually thrives between 15 and $30 \mathrm{~m}$ (e.g. Murray, 2006). Cassidulina carinata and Bulimina marginata, almost absent in the living fauna exhibit fairly contributions in the canyon sites Gitan 1 and Gitan 3. Therefore, even if sedimentary features and living foraminiferal fauna indicate a quite quiescent environment at this terrace site, the occurrence of large quantities of inner shelf and upper canyon axis taxa throughout the core suggest the presence of processes other than turbidity currents responsible for downslope transport. As documented in the inactive Cap-Ferret canyon, downslope transports of foraminifera can also take place in bottom nepheloid layers (Duros et al., 2014). Bolliet et al. (2014) observed such phenomena at a flank site located at $560 \mathrm{~m}$ in the Capbreton canyon (site FC9 K, Figure 1, Table 1). They observed exactly the same dominant species in the dead fauna (i.e. Cibicides lobatulus, Cassidulina carinata and Bulimina marginata) and concluded that these taxa were supplied by recurrent nepheloid currents. Hence, the study of dead assemblages, especially the identification of reworked foraminifera, can also give important clues about the sedimentary dynamics.

On the terrace site Gitan 6, the 3-4 $\mathrm{cm}$ sediment level which may corresponds to an hemipelagic or turbiditic silty-clay is mainly composed of autochthonous taxa (Figure 9, Table 3). The sandy $7-8 \mathrm{~cm}$ level is constituted by an admixture of autochthonous $(60 \%)$ and allochthonous $(40 \%)$ species. The main dead species is the epiphytic Planorbulina mediterranensis. Consequently, this deep terrace $(1454 \mathrm{~m})$, located $24 \mathrm{~m}$ above the canyon axis, constitutes a deposition area of inner shelf species.

\section{Conclusions}

Sedimentary features indicate that frequent sedimentary disturbances of different magnitudes (i.e. turbidite deposits, sediment resuspension and accumulation) occur along the Capbreton submarine canyon. Along the 6 studied sites, different foraminiferal responses to 


\section{ACCEPTED MANUSCRIPT}

various sedimentary patterns are observed revealing the complexity of this canyon environment (Figure 10):

(1) Foraminiferal communities with low to moderate standing stocks and low diversity, which are dominated by pioneer species such as Fursenkoina bradyi, Reophax dentaliniformis and Technitella melo, are observed in middle canyon axis and lower canyon axis and lower terrace sites (Gitan 3, Gitan 5 and Gitan 6). Repeated frequency of sedimentary disturbances recorded at Gitan 5 and 6 may probably sustain foraminiferal fauna in an early stage of recolonization.

(2) A low-diversity with an extremely high density of secondary colonizer, Bolivina subaenariensis is observed at the terrace site Gitan 2. This opportunistic taxon occupies a superficial microhabitat. Such peculiar faunal feature indicates strongly food-enriched sediment but extremely unstable conditions. This is consistent with the very high amount of fine-grained sediment which accumulates at this terrace.

(3) At the upper canyon site Gitan 1 (301 m), the more diverse assemblage dominated by Bolivina subaenariensis and Bulimina marginata with a lower standing stock compared to Gitan 2 seems to belong to a second generation of colonizers. Foraminiferal fauna at Gitan 1 appears to represent an advanced stage of ecosystem colonization after the occurrence of a turbidite deposit.

(4) Moderate standing stocks, diverse assemblage, a quite deep microhabitat and an absence of pioneer species is only observed at the terrace site Gitan 4. According to sedimentary features, this terrace seems more quiescent in terms of hydro-sedimentary conditions compared to all other sites. Such stable conditions appear to be suitable to the development of a dense and diverse foraminiferal community.

To monitor the subsequent development of the living foraminiferal fauna resamplings of the same locations are planned in future at the same seasonal period.

Finally, the identification of numerous neritic allochthonous species in the dead foraminiferal fauna at all studied sites indicates that reworked tests are mainly transported from inner shelf areas $(<60 \mathrm{~m})$ into the Capbreton canyon area. 


\section{Appendix A.}

Taxonomic list of major benthic foraminifera species $(>5 \%)$.

\section{Appendix B.}

Census data (non normalized values) for living benthic foraminifera in the $>150 \mu \mathrm{m}$ size fraction for all 6 stations.

\section{Appendix C.}

Absolute and relative abundances of dead benthic foraminifera in the $>150 \mu \mathrm{m}$ size fraction for all 6 stations.

\section{Acknowledgements}

We thank the captain and crew of the $R / V$ "Pourquoi Pas?"(IFREMER) and all participants to the GITAN cruise in particular the chief scientist Samuel Toucanne. François Beny is also gratefully acknowledge for his help during the sediment core-samplings. We gratefully thank Christophe Fontanier for his useful advice and comments on the original manuscript. The data used in this work was obtained during the Gitan cruise which had been carried out within the framework of the French TANDEM project (ANR-11-RSNR-0002301). We thank the two anonymous reviewers and the associate editor for their thorough and helpful comments on the manuscript and Imants G. Priede for his useful editorial suggestions and corrections.

\section{References}

Anschutz, P., Jorissen, F.J., Chaillou, G., Abu-Zied, R., Fontanier, C., 2002. Recent turbidite deposition in the eastern Atlantic: Early diagenesis and biotic recovery. Journal of Marine Research 60, 835-854.

Bernhard, J.M., 1988. Postmortem vital staining in benthic foraminifera: duration and importance in population and distributional studies. Journal of Foraminiferal Research 18, 143-146.

Bernhard, J.M., 1992. Benthic foraminiferal distribution and biomass related to pore-water oxygen content: central California continental slope and rise. Deep-Sea Research Part I 39, 585-605.

Bernhard, J.M., 2000. Distinguishing live from dead foraminifera: methods review and proper applications. Micropaleontology 46 (1), 38-46. 


\section{ACCEPTED MANUSCRIPT}

Bolliet, T., Jorissen, F.J., Schmidt, S., Howa, H., 2014. Benthic foraminifera from Capbreton Canyon revisited; faunal evolution after repetitive sediment disturbance. Deep-Sea Research Part II 104, 319-334.

Bouma, A.H., 1962. Sedimentology of some flysch deposits. Elsevier, Amsterdam, 168 pp. Bourillet, J.-F., Zaragosi, S., Mulder, T., 2006. The French Atlantic margin and the deep sea submarine systems. Geo-Marine Letter 26 (6), 311-315.

Brocheray, S., Cremer, M., Zaragosi, S., Schmidt, S., Eynaud, F., Rossignol, L., Gillet, H., 2014. 2000 years of frequent turbidite activity in the Capbreton Canyon (Bay of Biscay). Marine Geology 347, 136-152.

Cearreta, A., 1989. Foraminiferal assemblages in the ria of San Vicente de la Barquera (Cantabria, Spain). Revista española de micropaleontología 21, 67-80.

Corliss, B.H., Emerson, S., 1990. Distribution of Rose Bengal stained deep-sea benthic foraminifera from the Nova Scotia continental margin and Gulf of Maine. Deep-Sea Research Part I 37, 381-400.

de Stigter, H.C., van der Zwaan, G.J., Langone, L., 1999. Differential rates of benthic foraminiferal test production in surface and subsurface sediment habitats in the southern Adriatic Sea. Palaeogeography, Palaeoclimatology, Palaeoecology 149, 67-88.

Donnici, S., Serandrei Barbero, R., 2002. The benthic foraminiferal communities of the northern Adriatic continental shelf. Marine Micropaleontology 44, 93-123.

Duchemin, G., Fontanier, C., Jorissen, F.J., Barras, C., Griveaud, C., 2007. Living small-sized $(63-150 \mathrm{~mm})$ foraminifera from mid-shelf to mid-slope environments in the Bay of Biscay. J. Foraminiferal Research 37, 12-32.

Duros, P., Fontanier, C., Metzger, E., Pusceddu, A., Cesbron, F., de Stigter, H.C., Bianchelli, S., Danovaro, R., Jorissen, F.J., 2011. Live (stained) benthic foraminifera in the Whittard Canyon, Celtic margin (NE Atlantic). Deep-Sea Research Part I 58, 128-146.

Duros, P., Fontanier, C., Metzger, E., Cesbron, F, Deflandre, B., Schmidt, S., Buscail, R., Zaragosi, S., Kerhervé, P., Jorissen, F.J., 2013. Live (stained) benthic foraminifera from the Cap-Ferret Canyon (Bay of Biscay, NE Atlantic): a comparison between the canyon axis and the surrounding areas. Deep-Sea Research Part I 74, 98-114.

Duros, P., Jorissen,F.J., Cesbron,F., Zaragosi,S., Schmidt,S., Fontanier,C., 2014. Study of benthic foraminiferal thanatocoenoses from the Cap-Ferret Canyon area (NE Atlantic): A complex interplay between hydro-sedimentary and biological processes. Deep-Sea Research Part II 104, 145-163.

Ernst, S., Duijnstee, I., van der Zwaan, B., 2002. The dynamics of the benthic foraminiferal microhabitat: recovery after experimental disturbance. Marine Micropaleontology 46, 343361.

Fontanier, C., Jorissen, F.J., Chaillou, G., Anschutz, P., Grémare, A., Griveaud, C., 2005. Live foraminiferal faunas from a $2800 \mathrm{~m}$ deep lower canyon station from the Bay of Biscay: faunal response to focusing of refractory organic matter. Deep Sea Research Part I 52, 1189 1227.

Fontanier, C., Jorissen, F., Geslin, E., Zaragosi, S., Duchemin, G., Laversin, M., Gaultier, M., 2008. Live and dead foraminiferal faunas from Saint-Tropez Canyon (Bay of Fréjus): observations based on situ and incubated cores. Journal of Foraminiferal Research 38, 137156.

Frew, R.D., Dennis, P.F., Heywood, K.J., Meredith, M.P., Boswell, S.M., 2000. The oxygen isotope composition of water masses in the northern North Atlantic. Deep Sea Research Part I 47, 2265-2286.

Frezza, V., Carboni, M.G., 2009. Distribution of recent foraminiferal assemblages near the Ombrone River mouth (Northern Tyrrhenian Sea, Italy). Revue de Micropaléontologie 52, 43-66. 


\section{ACCEPTED MANUSCRIPT}

Gaudin, M., Berné , S., Jouanneau, J.M., Palanques, A., Puig, P., Mulder, T., Cirac, P., Rabineau, M., Imbert, P., 2006. Massive sand beds attributed to deposition by dense water cascades in the Bourcart canyon head, Gulf of Lions (northwestern Mediterranean Sea). Marine Geology 234, 111-128.

Goineau, A., Fontanier, C., Jorissen, F.J., Lansard, B., Buscail, R., Mouret, A., Kerhervé, P., Zaragosi, S., Ernoult, E., Artéro, C., Anschutz, P., Metzger, E., Rabouille, C., 2011. Live (stained) benthic foraminifera from the Rhône prodelta (Gulf of Lion, NW Mediterrenean): environmental controls on a river-dominated shelf. Journal of Sea Research 65, 58-75.

Hess, S., Kuhnt, W., 1996. Deep-sea benthic foraminiferal recolonization of the 1991 Mt. Pinatubo ash layer in the South China Sea. Marine Micropaleontology 28, 171-197.

Hess, S., Jorissen, F.J., Venet, V., Abu-Zied, R., 2005. Benthic foraminiferal recovery after recent turbidite deposition in Cap Breton canyon, Bay of Biscay. Journal of Foraminiferal Research, 35 (2), 114-129.

Hess, S., Jorissen, F.J., 2009. Distribution patterns of living benthic foraminifera from Cap Breton canyon, Bay of Biscay: Faunal response to sediment instability. Deep-Sea Research Part I 56 (9), 1555-1578.

Hsu, S.K., Kuo, J., Lo, C.L., Tsai, C.H., Doo, W.B., Ku, C.Y., Sibuet, J.C., 2008. Turbidity currents, submarine landslides and the 2006 Pingtung earthquake off SW Taiwan. Terrestrial, Atmospheric and Oceanic Sciences 19, 767-772.

Ikeya, N., 1970. Population ecology of benthonic foraminifera in Ishikari Bay, Hokkaido, Japan. Records of Oceanographic Works in Japan 10, 173-191.

Klingebiel, A., Legigan, P., 1978. Histoire géologique des divagations de l'Adour. In: Acte du Congrès de Bayonne des 28 et 29 Octobre 1978 organisé pour le IV ${ }^{\text {ème }}$ Centenaire du Détournement de l'Adour, Bayonne, pp. 23-34.

Koho, K.A., Kouwenhoven, T.J., de Stigter, H.C., van der Zwaan, G.J., 2007. Benthic foraminifera in the Nazaré Canyon, Portuguese continental margin: Sedimentary environments and disturbance. Marine Micropaleontology, 66 (1), 27-51.

Koho, K.A., García, R., de Stigter, H.C., Epping, E., Koning, E., Kouwenhoven, T.J., van der Zwaan, G.J., 2008. Sedimentary labile organic carbon and pore water redox control on species distribution of benthic foraminifera: A case study from Lisbon-Setúbal Canyon (southern Portugal). Progress in Oceanography, 79 (1), 55-82.

Langezaal, A.M., Jorissen, F.J., Braun, B., Chaillou, G., Fontanier, C., Anschutz, P., Van der Zwaan, G.J., 2006. The influence of seasonal processes on geochemical profiles and foraminiferal assemblages on the outer shelf of the Bay of Biscay. Continental Shelf Research $26,1730-1755$.

Le Suavé, R., Normand, A., Mazé, J.-P., Loubrieu, B., Le Drézen, E., Bourillet, J.-F., Coutelle, A., 1999. Synthèse bathymétrique et imagerie acoustique. Zone économique exclusive (ZEE), Atlantique Nord-Est. 6 cartes bathymétriques au 1/250,000, 2 cartes de réflectivité au 1/500,000, notice «La marge Nord du golfe de Gascogne: connaissance générale et apport des nouvelles synthèses de données multifaisceau ». Ifremer.

Mulder, T., Weber, O., Anschutz, P., Jorissen, F.J., Jouanneau, J.-M., 2001. A few monthsold storm-generated turbidite deposited in the Capbreton canyon (Bay of Biscay, SW France). Geo-Marine Letters, 21, 149-156.

Mulder, T., Cirac, P., Gaudin, M., Bourillet, J.F., Tranier, J., Normand, A., Weber, O., Griboulard, R., Jouanneau, J.M., Anschutz, P., Jorissen, F.J., 2004. Understanding continentocean sediment transfer. Eos 85 (257), 261-262. 


\section{ACCEPTED MANUSCRIPT}

Mulder, T., Zaragosi, S., Garlan, T., Mavel, J., Cremer, M., Sottolichio, A., Sénéchal, N., Schmidt, S., 2012. Present deep-submarine canyons activity in the Bay of Biscay (NE Atlantic). Marine Geology 295-298, 113-127.

Murray, J.W., 1991. Ecology and Palaeoecology of Benthic Foraminifera. Longman Scientific and Technical, Harlow, p. 397.

Murray, J.W., 2006. Ecology and Applications of Benthic Foraminifera. Cambridge University Press, p. 426.

Nesteroff, W., Duplaix, S., Sauvage, J., Lancelot, Y., Melières, F., Vincent, E., 1968. Les dépôts récents du canyon de Capbreton. Bulletin de la Société Géologique de France 7, 218 252 .

Robbins, J., Edgington, D.N., 1975. Determination of recent sedimentation rates in Lake Michigan using ${ }^{210} \mathrm{~Pb}$ and ${ }^{137} \mathrm{Cs}$. Geochimica Cosmochimica Acta 39, 285-304.

Rowe, G.T., Polloni, P.T., Haedrich, R.L., 1982. The deep sea-benthos on the continental margin of the northwest Atlantic. Deep-Sea Research I 29, 257-278.

Schmidt, S., Howa, H., Mouret, A., Lombard, F., Anschutz, P., Labeyrie, L., 2009. Particle fluxes and recent sediment accumulation on the Aquitanian margin of Bay of Biscay. Continental Shelf Research 29, 1044-1052.

Sen Gupta, B.K., 1999. Systematics of modern Foraminifera. In: Sen Gupta B.K. (Editor), Modern Foraminifera. Kluwer Academic Publishers, 7-36.

Shepard, F.P., Dill, R.F., 1966. Submarine canyons and other sea valleys. Rand McNally Company, Chicago.

Soetaert, K., Heip, C., 1995. Nematode assemblages of deep-sea and shelf break sites in the North Atlantic and Mediterranean Sea. Marine Ecology Progress Series 125, 171-183.

Sturrock, S., Murray, J.W., 1981. Comparisons of low energy middle shelf foraminiferal faunas: Celtic Sea and western English Channel. In Neale, J.W. and Brasier, M. D., eds. Microfossils from Recent and Fossil Shelf Seas. Chichester: Ellis Horwood, pp. 250-260.

Stow, D.A.V., Shanmugam, G., 1980. Sequence of structures in fine-grained turbidites; comparison of Recent deep-sea and ancient flysch sediments. Sedimentary Geology, 25(1-2), $23-42$.

Toucanne, S., 2015. GITAN cruise, RV Pourquoi pas ?, http://dx.doi.org/10.17600/15017800

Van Aken, H.M., 2000a. The hydrography of the mid-latitude Northeast Atlantic Ocean: I: the deep water masses. Deep-Sea Research Part I 47 (5), 757-788.

Van Aken, H.M., 2000b. The hydrography of the mid-latitude Northeast Atlantic Ocean: II: the intermediate water masses. Deep-Sea Research Part I 47, 789-824.

Vénec-Peyré, M. T., Le Calvez, Y., 1988. Les foraminifères épiphytes de l'herbier de Posidonies de Banyuls-sur-Mer (Méditerranée occidentale): études des variations spatiotemporelles du peuplement. Cahiers de micropaléontologie 3, 21-40.

Vetter, E.W., Dayton, P.K., 1998. Macrofaunal communities within and adjacent to a detritusrich submarine canyon system. Deep-Sea Research I 45, 25-54.

Walton, W.R., 1952. Techniques for recognition of living foraminifera. Contribution Cushman Foundation Foraminiferal Research 3, 56-60. 


\section{ACCEPTED MANUSCRIPT}

Duros et al., Figure 1

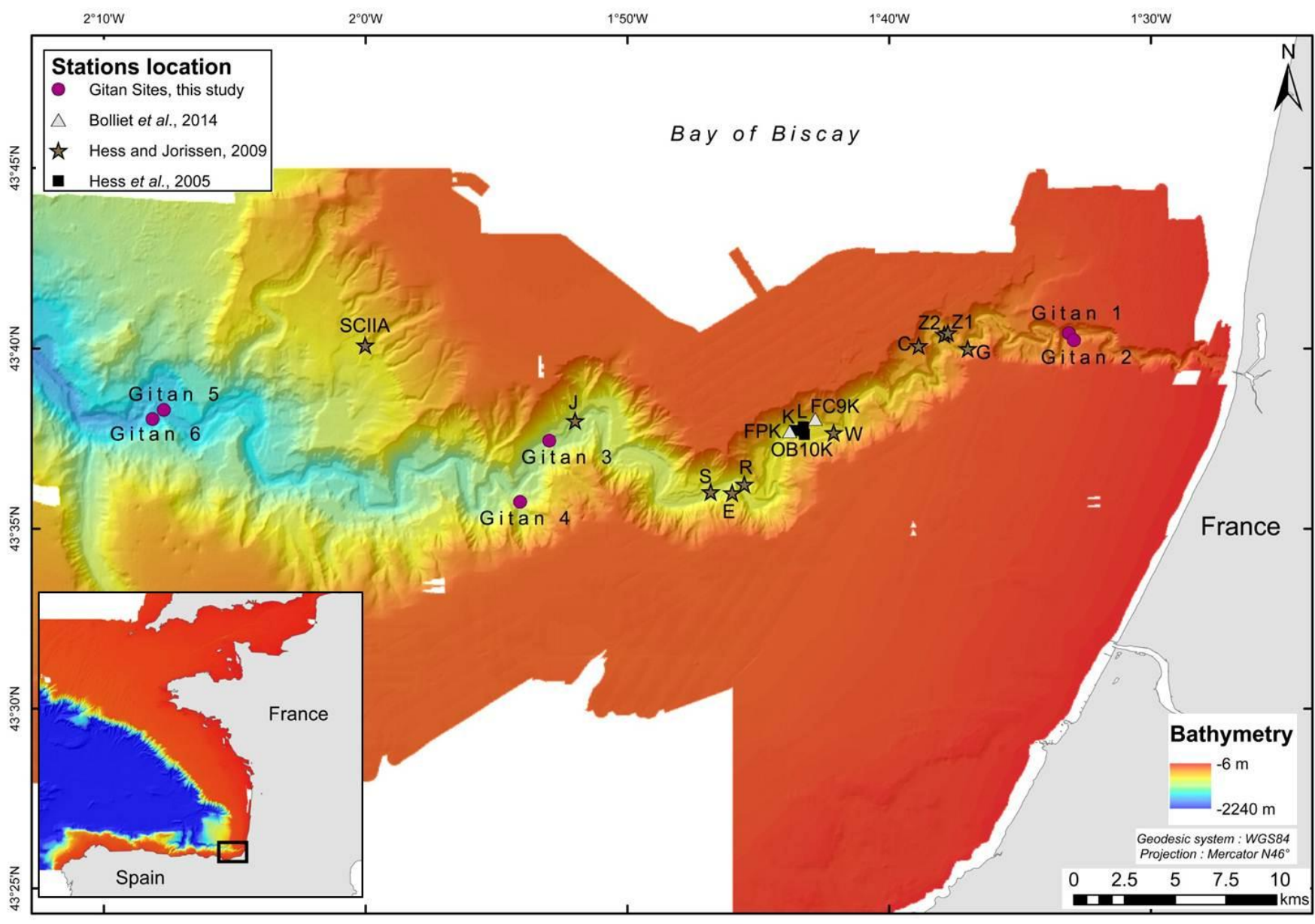

Figure 1 - Study area, bathymetry and geomorphological position of the 6 investigated sites. Gitan 1, 3 and 5 are located in the Capbreton canyon axis and Gitan 2, 4 and 6 are positioned on the adjacent terraces (from Le Suavé et al., 1999 and Bourillet et al., 2006). All cores previously documented by Hess et al. (2005), Hess and Jorissen (2009) and Bolliet et al. (2014) are also located. 
Duros et al., Figure 2
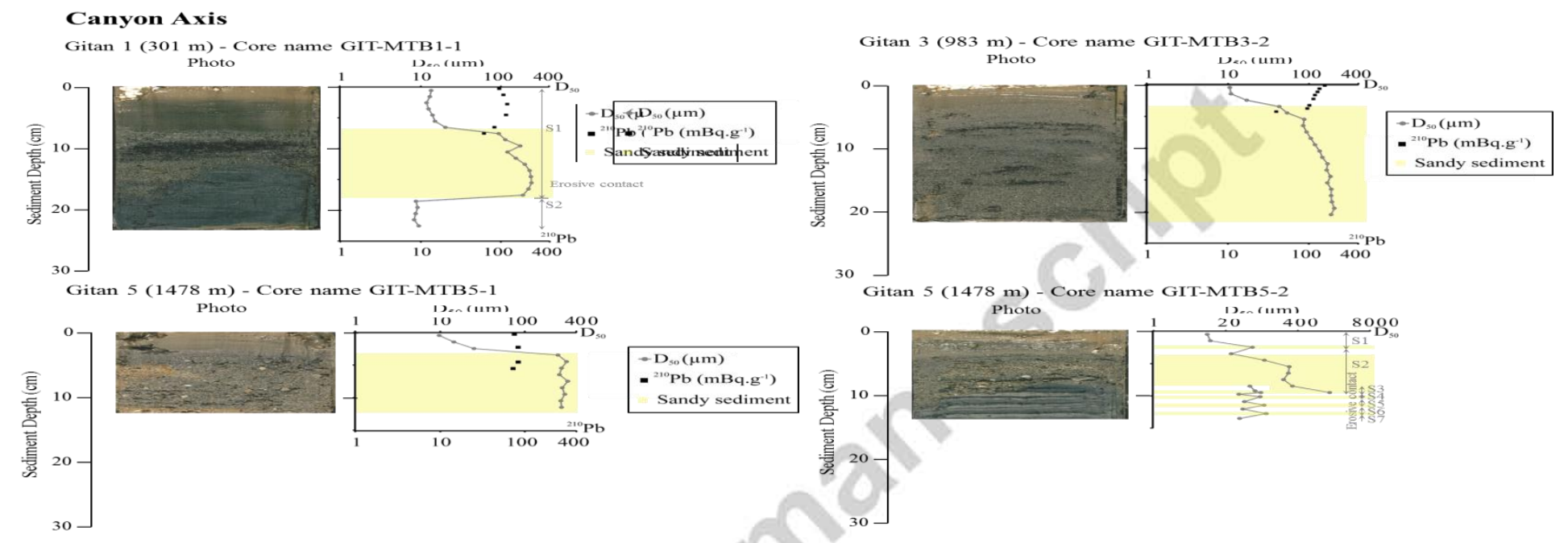

Figure 2 - Photographs, grain sizes of the $50^{\text {th }}$ percentiles $\left(\mathrm{D}_{50}, \mu \mathrm{m}\right)$ and ${ }^{210} \mathrm{~Pb}_{\mathrm{xs}}$ activity profiles (mBq. $\mathrm{g}^{-1}$ ) of cores collected along the Capbreton canyon axis. The two sediment cores from site Gitan 5 (GIT-MTB5-1 and GIT-MTB5-2) show different sedimentary records and are presented on this figure. ${ }^{210} \mathrm{~Pb}_{\mathrm{xs}}$ activities were determined in the topmost silty-clay sediment unit (no data below $9 \mathrm{~cm}$ ) of one core per station. 
Duros et al., Figure 3

\section{Terraces}

Gitan 2 (251 m) - Core name GIT-MTB2-2

Photo

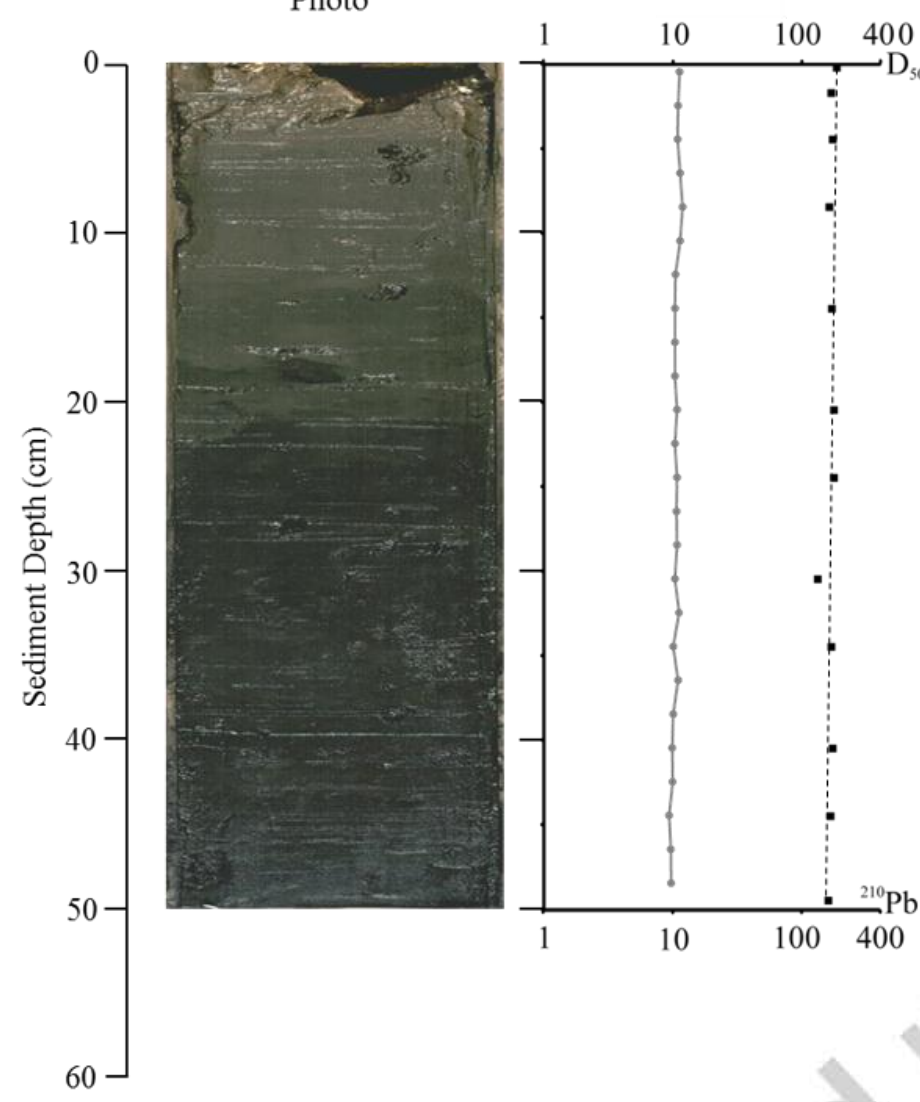

Gitan 4 (894 m) - Core name GIT-MTB4-1

Photo

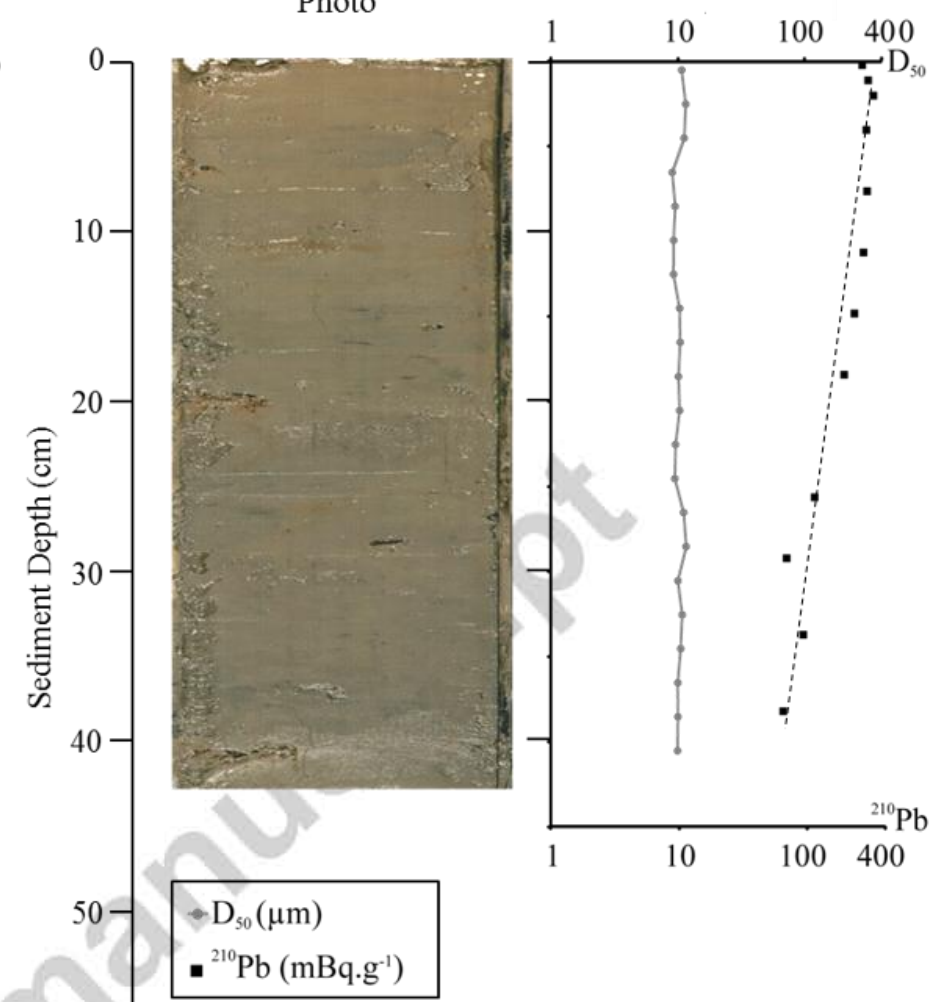

Gitan 6 (1454 m) - Core name GIT-MTB6-1

Photo

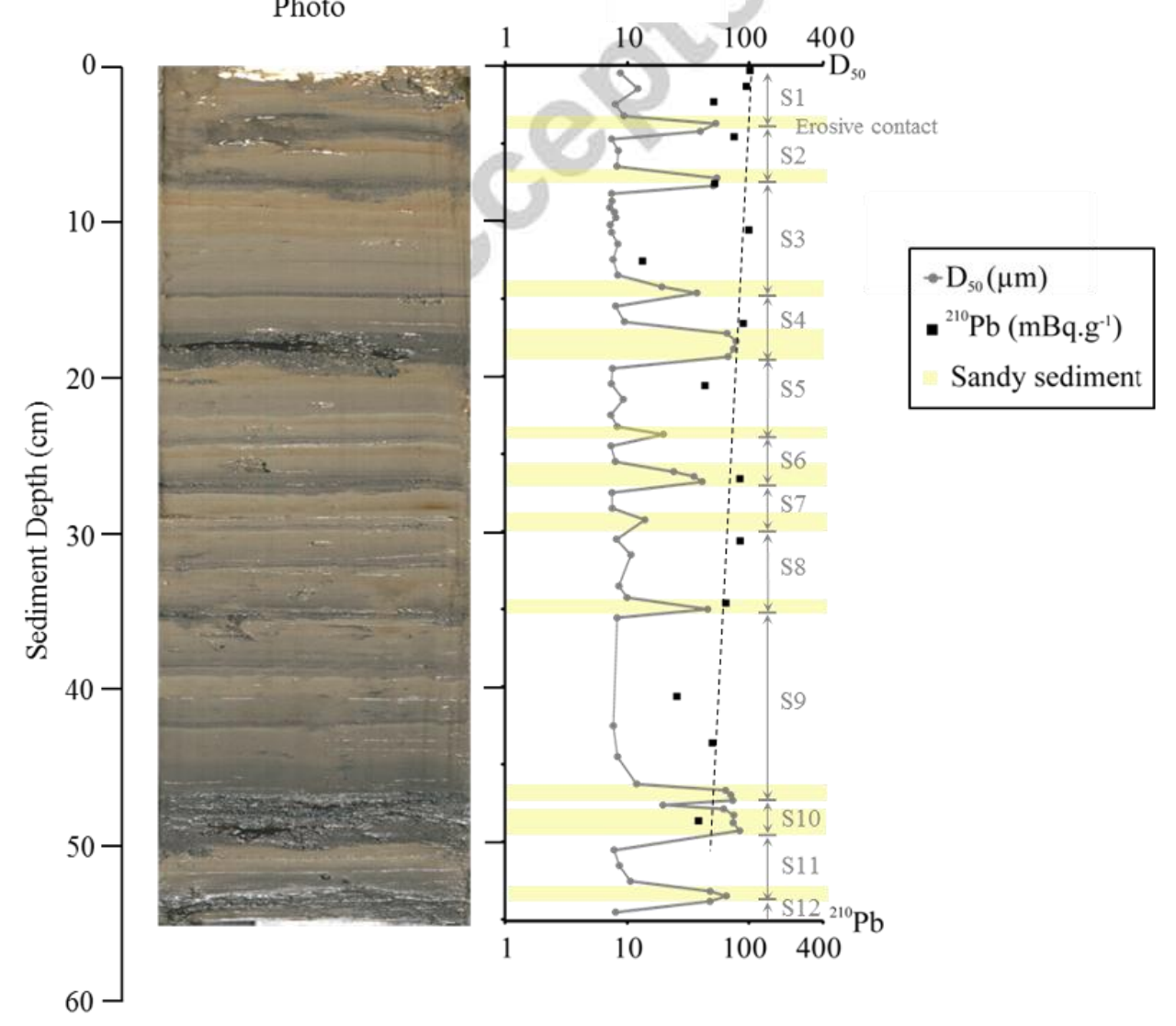


Figure 3 - Photographs, grain sizes of the $50^{\text {th }}$ percentiles $\left(\mathrm{D}_{50}, \mu \mathrm{m}\right)$ and ${ }^{210} \mathrm{~Pb}_{\mathrm{xs}}$ activity profiles $\left(\mathrm{mBq} \cdot \mathrm{g}^{-1}\right)$ of cores collected along the Capbreton canyon terraces. The dashed lines show the regression used to estimate sedimentation rate.

Duros et al., Figure 4
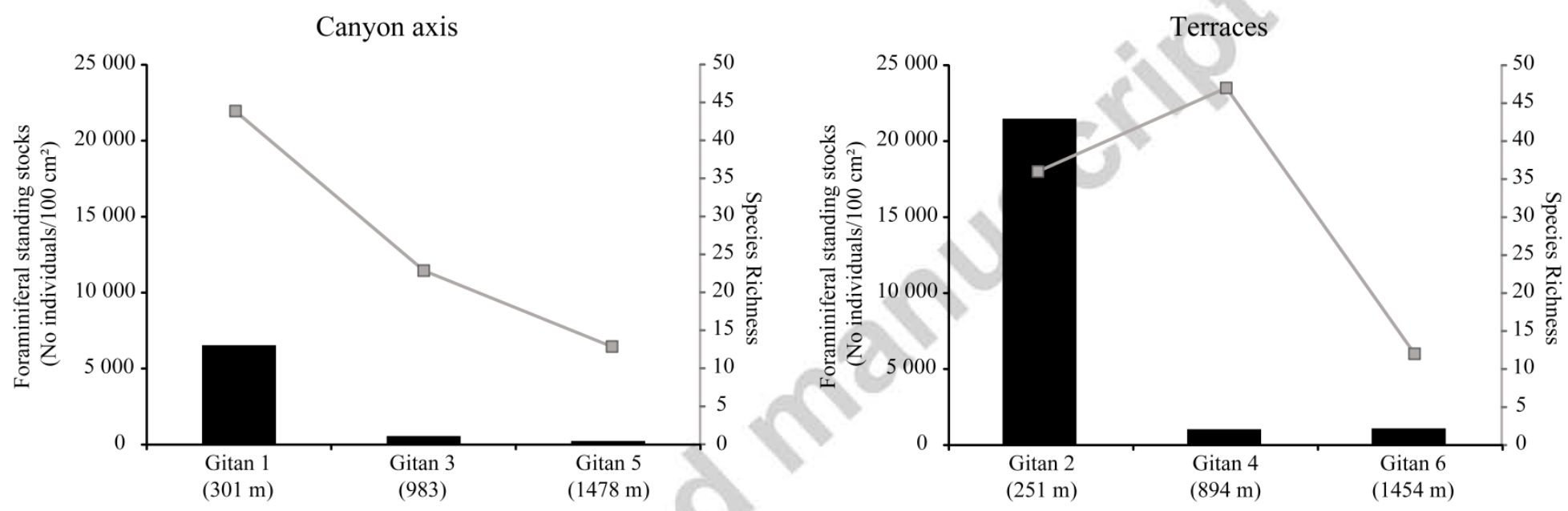

Figure 4 - Standing stocks (number of living individuals per $100 \mathrm{~cm}^{2}$, black columns) and species richness (grey line plots) of living benthic foraminifera $(>150 \mu \mathrm{m})$ along the Capbreton canyon axis and adjacent terraces. 
Duros et al., Figure 5

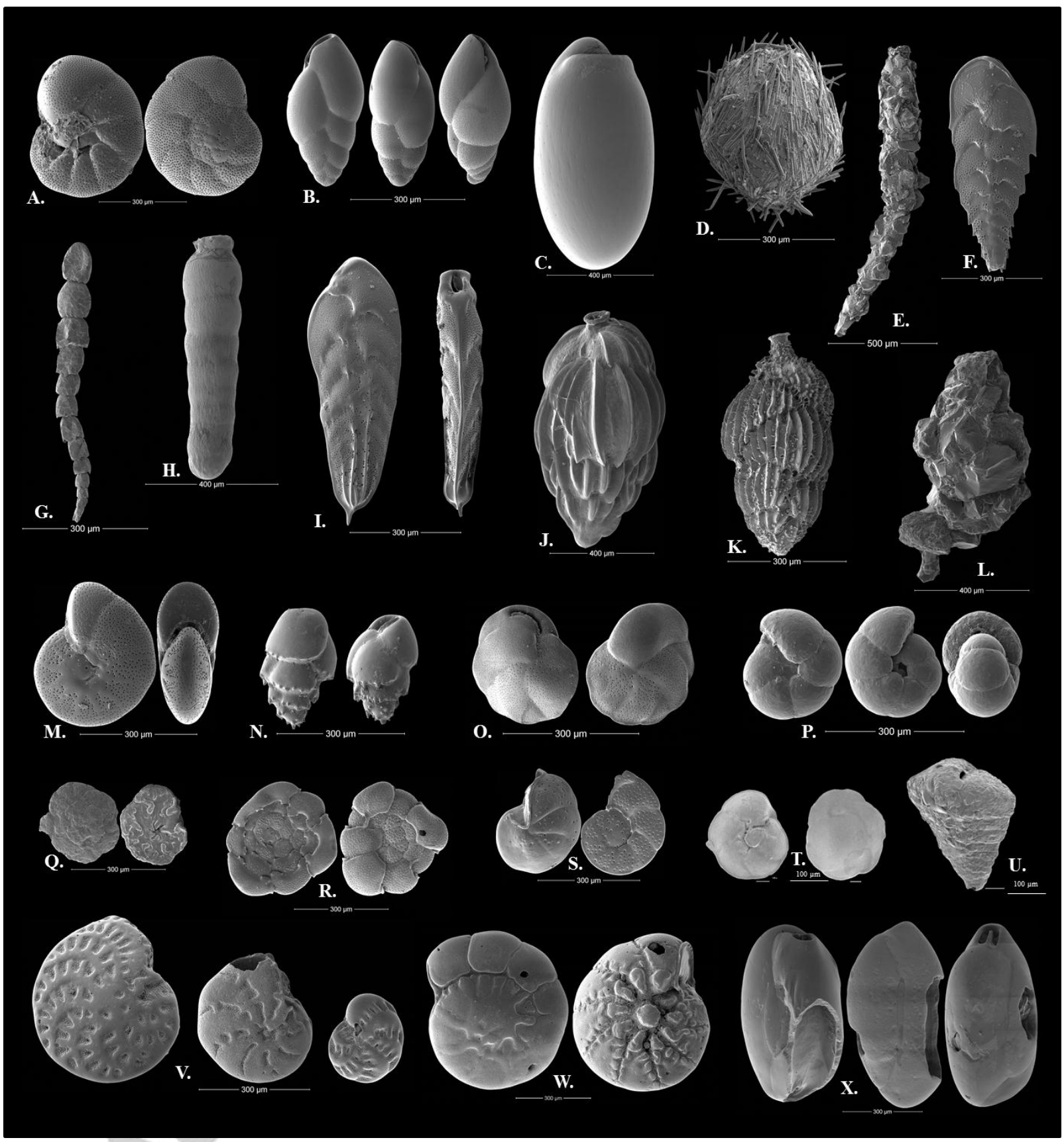

Figure 5 - SEM photographs of main foraminiferal species ( $>5 \% ;>150 \mu \mathrm{m}$ size fraction) observed at all investigated sites in the living (stained) and dead (unstained) faunas. A. Living Valvulineria bradyana (station Gitan 2, 0-1 cm). B. Living Fursenkoina bradyi (Gitan 3, 0-1 $\mathrm{cm}$ ). C. Living Chilostomella oolina (Gitan 6, 0-1 cm). D. Living Technitella melo (Gitan 3, 0-1 cm). E. Living Reophax dentaliniformis (Gitan 3, 0-1 cm). F. Living Bolivina alata (Gitan 4, 0-1 cm). G. Living Leptohalysis scottii (Gitan 1, 0-1 cm). H. Living Siphogenerina columellaris (Gitan 4, 0-1 cm). I. Living Bolivina subaenariensis (Gitan 2, 0-1 cm). J. Living Uvigerina mediterranea (Gitan 4, 0-1 cm). K. Living Uvigerina peregrina (Gitan 4, 0-1 cm). L. Living Reophax scorpiurus (Gitan 4, 0-1 cm). M. Living Melonis barleeanus (Gitan 4, 0-1 cm). N. Living Bulimina marginata (Gitan 1, 0-1 cm). O. Living Cassidulina carinata (Gitan 6, 0-1 cm). P. Living Haplophragmoides bradyi (Gitan 6, 0- 


\section{ACCEPTED MANUSCRIPT}

$1 \mathrm{~cm}$ ). Q. Dead Planorbulinella larvata (Gitan 3, 9-10 cm). R. Dead Planorbulina mediterranensis (Gitan 1, 9-10 cm). S. Dead Cibicides lobatulus (Gitan 1, 9-10 cm). T. Dead Gavelinopsis translucens (Gitan 4, 2-3 cm). U. Dead Textularia sagittula (Gitan 4, 2-3 cm). V. Dead Elphidium spp. (Gitan 1, 9-10 cm). W. Dead Ammonia beccarii (Gitan 5, 9-10 cm). X. Dead Quinqueloculina sp.1 (Gitan 5, 9-10 cm).

A) Relative abundances of the main species $(>5 \%)$

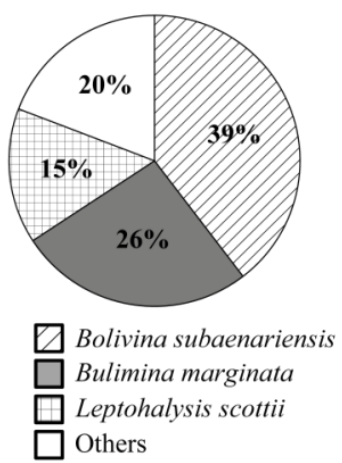

C) Relative abundances of the main species $(>\mathbf{5} \%)$

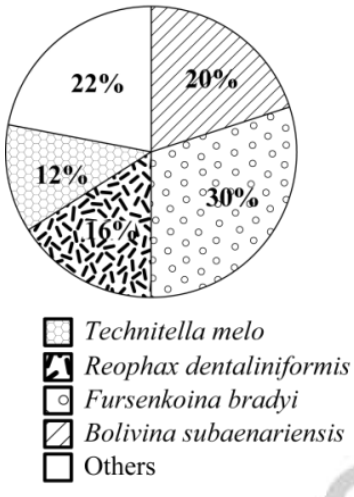

E) Relative abundances of the main species ( $>5 \%$ )

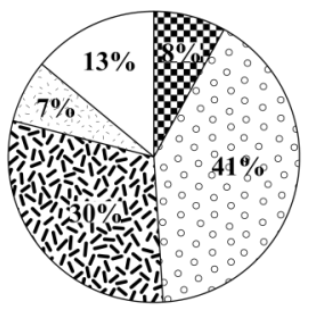

Leophax dentaliniformis $\square$ Uvigerina peregrina 0 Fursenkoina bradyi

Haplophragmoides bradyi Others

\section{Canyon axis}

Gitan 1 (301 m)

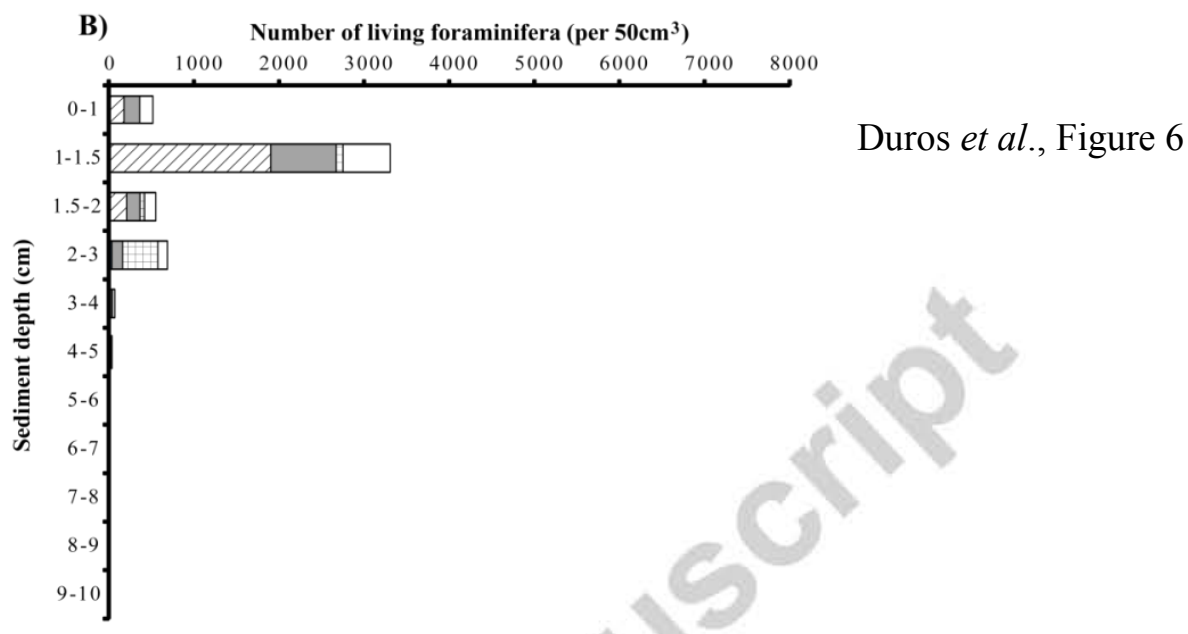

Gitan 3 (983 m)

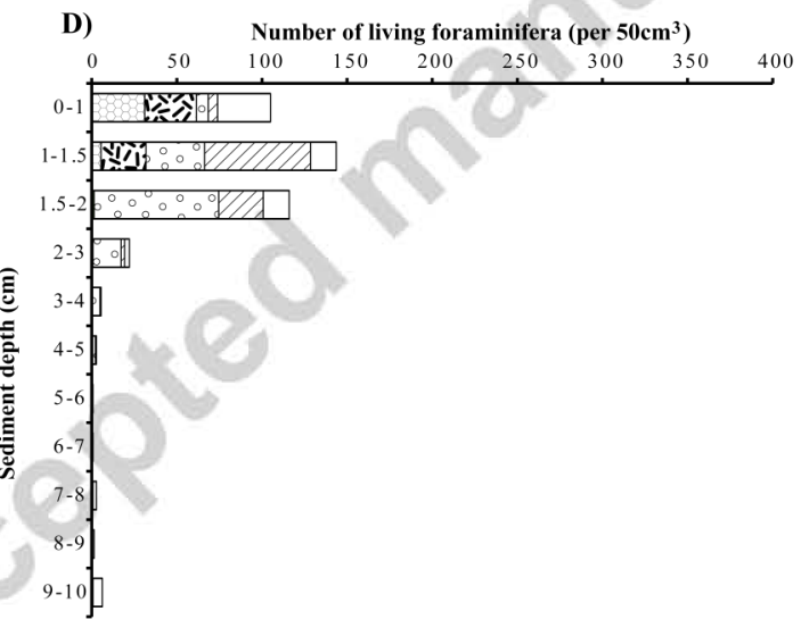

Gitan 5 (1478 m)

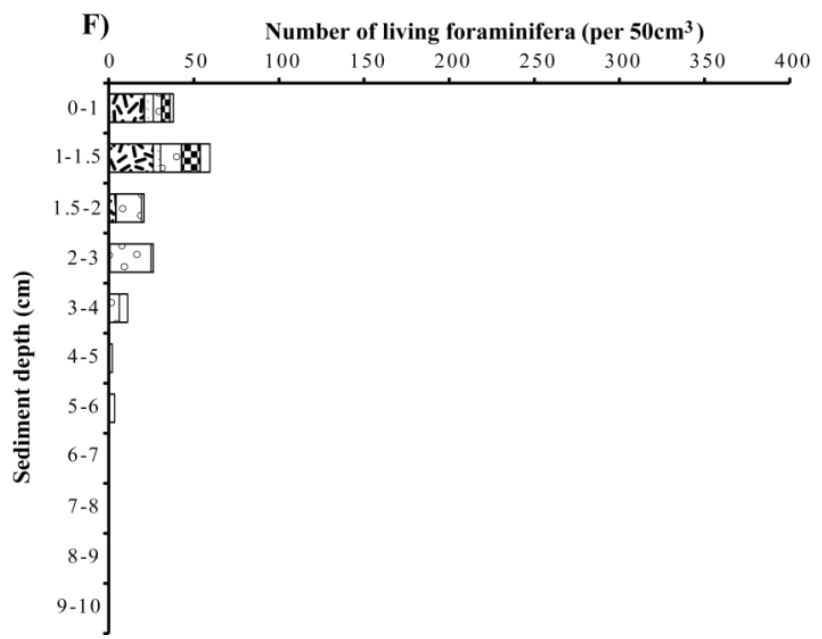


Figure 6 - (A, C, E) Relative abundance (\%) and (B, D, F) vertical distribution (standardized for a $50 \mathrm{~cm}^{3}$ sediment volume) of the main living species $(>5 \% ;>150 \mu \mathrm{m})$ observed along the canyon axis. Note the scale changes.

Duros et al., Figure 7

\section{Terrace}

A)

Relative abundances of the main species $(>5 \%)$

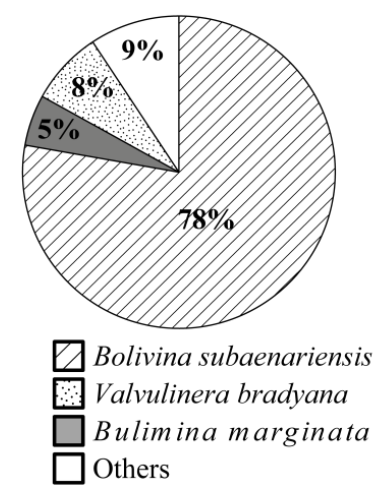

C) Relative abundances of the main species $(>5 \%)$

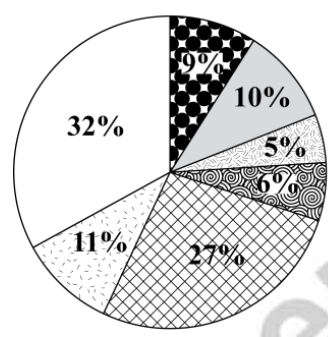

叉 Uvigerina mediterranea

$\square$ Uvigerina peregrina

Reophax scorpiurus

罚 Siphogenerina columellaris

$\square$ Melonis barleeanus

$\square$ Bolivina alata

$\square$ Others

E) Relative abundances of the main species $(>\mathbf{5 \%})$

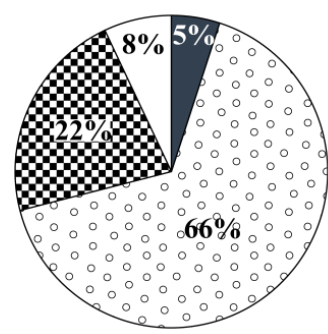

9 Fursenkoina bradyi

E. Haplophragmoides bradyi Chilostomella oolina $\square$ Others
Gitan 2 (251 m)

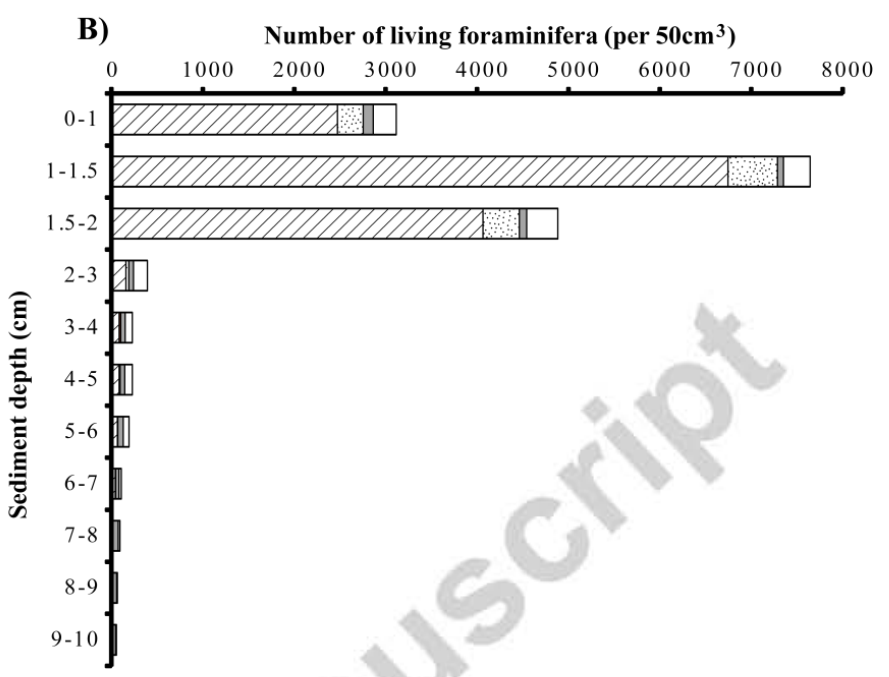

Gitan 4 (894 m)

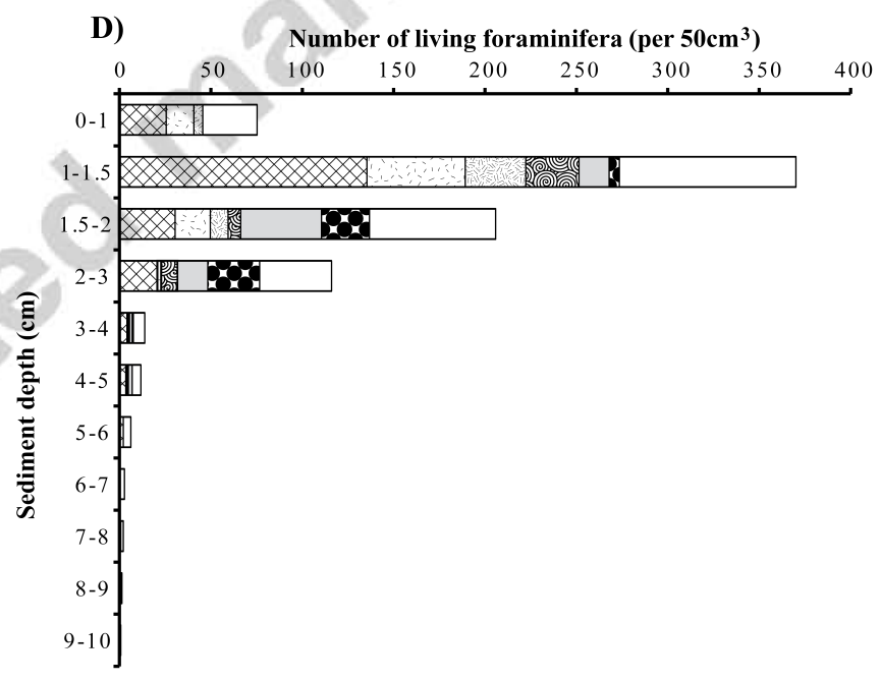

\section{Gitan 6 (1454 m)}

F)

Number of living foraminifera (per $50 \mathrm{~cm}^{3}$ )

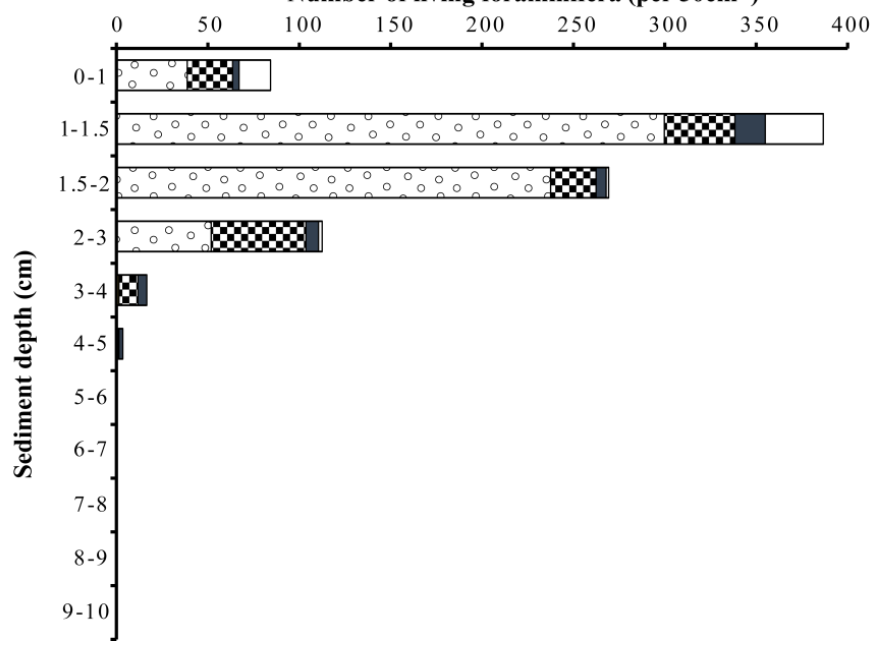


Figure 7 - (A, C, E) Relative abundance (\%) and (B, D, F) vertical distribution (standardized for a $50 \mathrm{~cm}^{3}$ sediment volume) of the main living species ( $\left.>5 \% ;>150 \mu \mathrm{m}\right)$ observed on adjacent terraces. Note the scale changes.

\section{Canyon axis}

\section{Gitan 1 (308 m)}
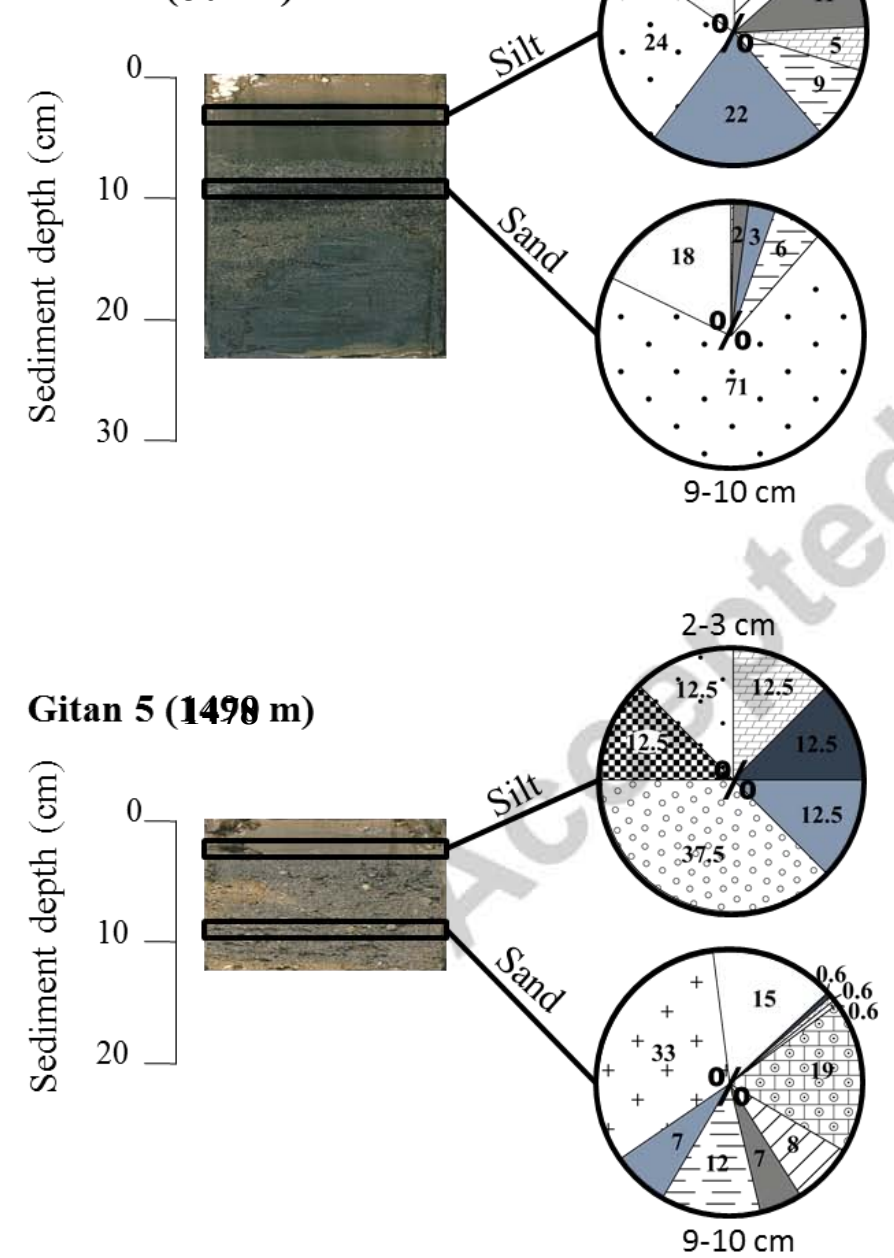

Duros et al., Figure 8

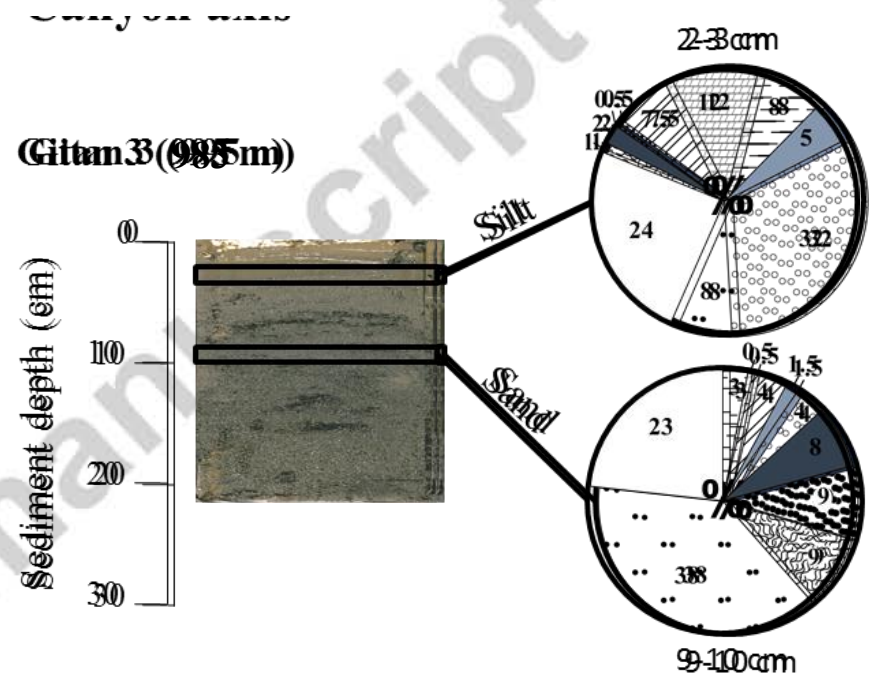

Figure 8 - Relative abundance of the main species $(>5 \%)$ observed in the dead fauna $(>150 \mu \mathrm{m})$ along the canyon axis in two different sediment levels, $2-3 \mathrm{~cm}$ (silty level) and 9-10 cm (sandy level). 


\section{ACCEPTED MANUSCRIPT}

Duros et al., Figure 9

\section{Terrace}

Gitan $2(260 \mathrm{~m})$

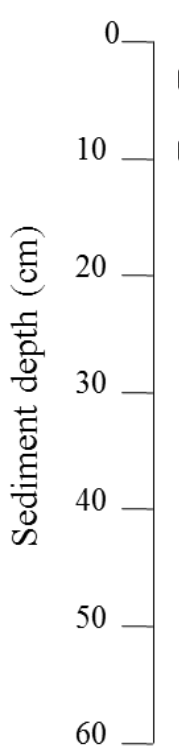

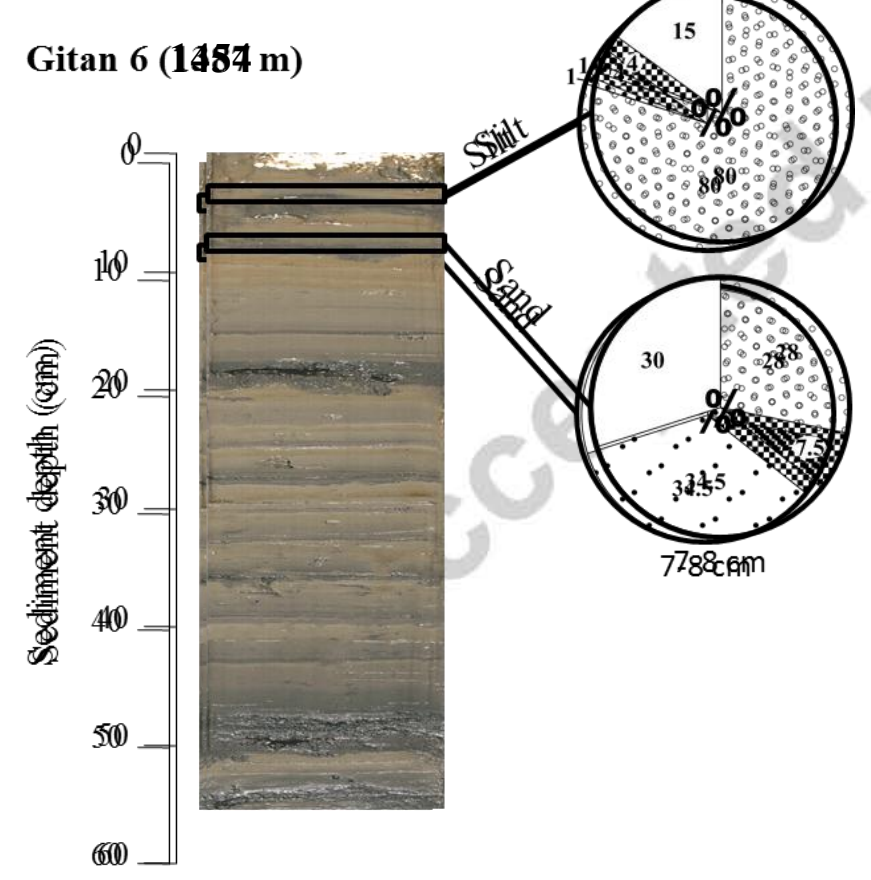

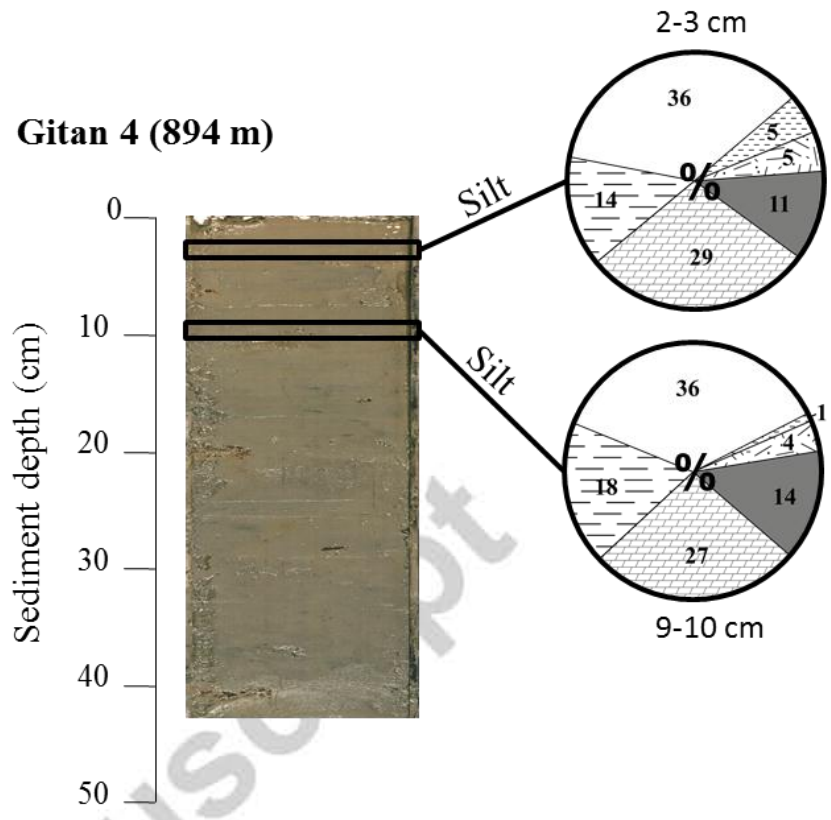

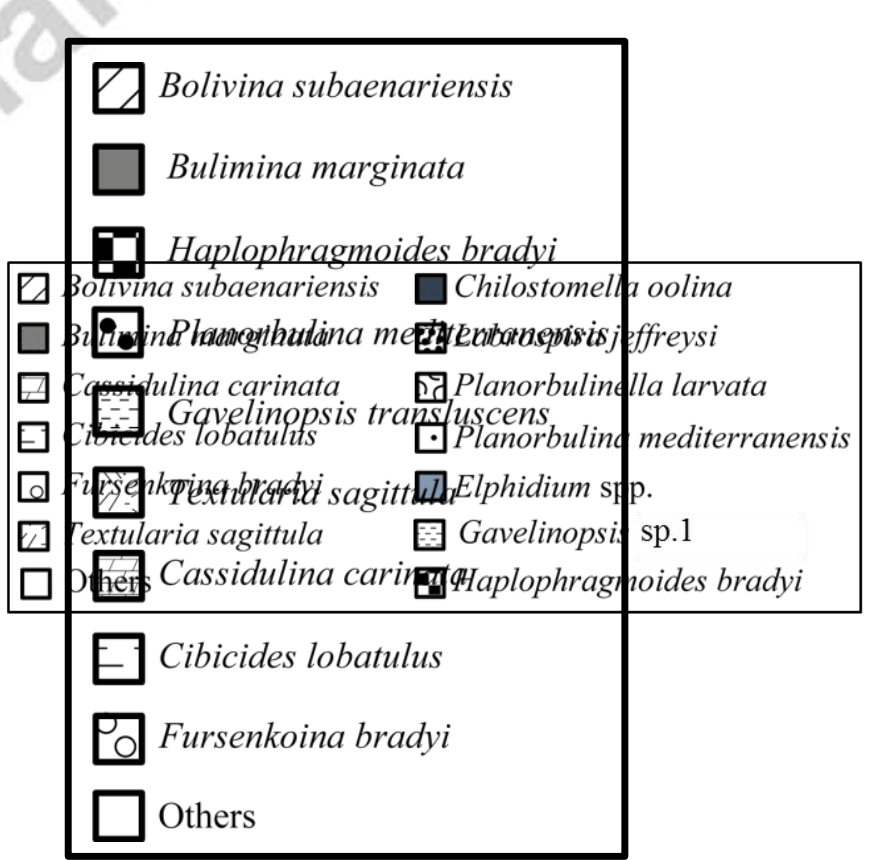

Figure 9 - Relative abundance of the main species $(>5 \%)$ observed in the dead fauna $(>150 \mu \mathrm{m})$ along adjacent terraces in two different sediment levels, 2-3 cm (silty level) and 9-10 cm (sandy or silty level). 


\section{Turbidites/}

High sediment

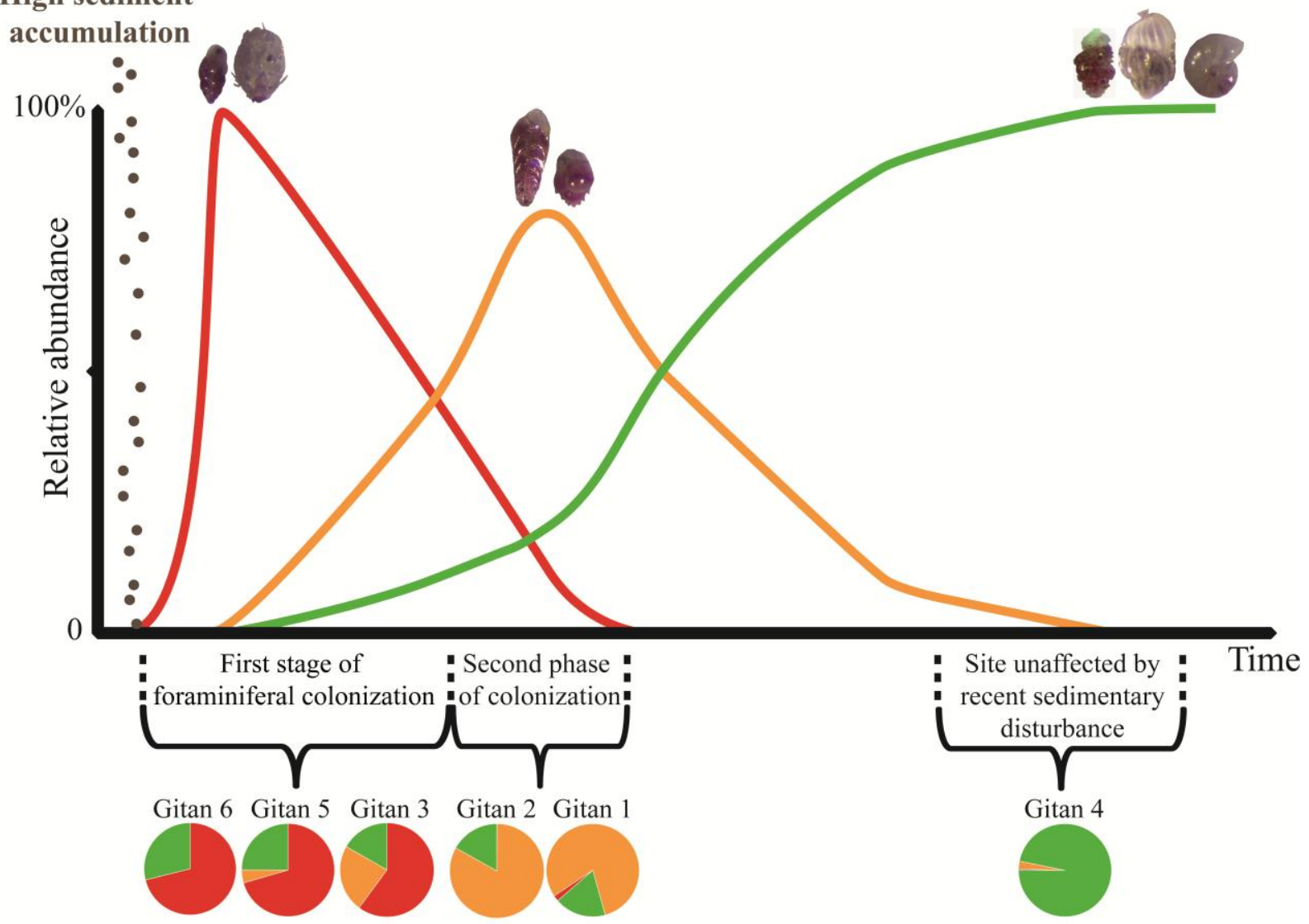

Pioneer colonizers (e.g. Fursenkoina bradyi, Technitella melo)

Secondary colonizers (e.g. Bolivina subaenariensis, Bulimina marginata)

Species thriving in rather stable environmental conditions (e.g. Uvigerina spp., Melonis barleeanus)

Figure 10 - Summarized schema which documents the various foraminiferal responses observed along the 6 studied sites sampled in August 2015. Gitan 1 (301 m), Gitan 3 (983 m) and Gitan 5 $(1478 \mathrm{~m})$ are located along the Capbreton canyon axis and Gitan $2(251 \mathrm{~m})$, Gitan $4(894 \mathrm{~m})$ and Gitan $6(1454 \mathrm{~m})$ on terraces at $50 \mathrm{~m}, 156 \mathrm{~m}$ and $24 \mathrm{~m}$ above the canyon axis, respectively. 


\section{ACCEPTED MANUSCRIPT}

Table 1 - Geographical position, water depth and sampling date of the 6 investigated stations in this study (Gitan 1 to Gitan 6) and of all previously documented sites in the Capbreton canyon area (Anshutz et al., 2002; Hess et al., 2005; Hess and Jorissen , 2009; Bolliet et al., 2014).

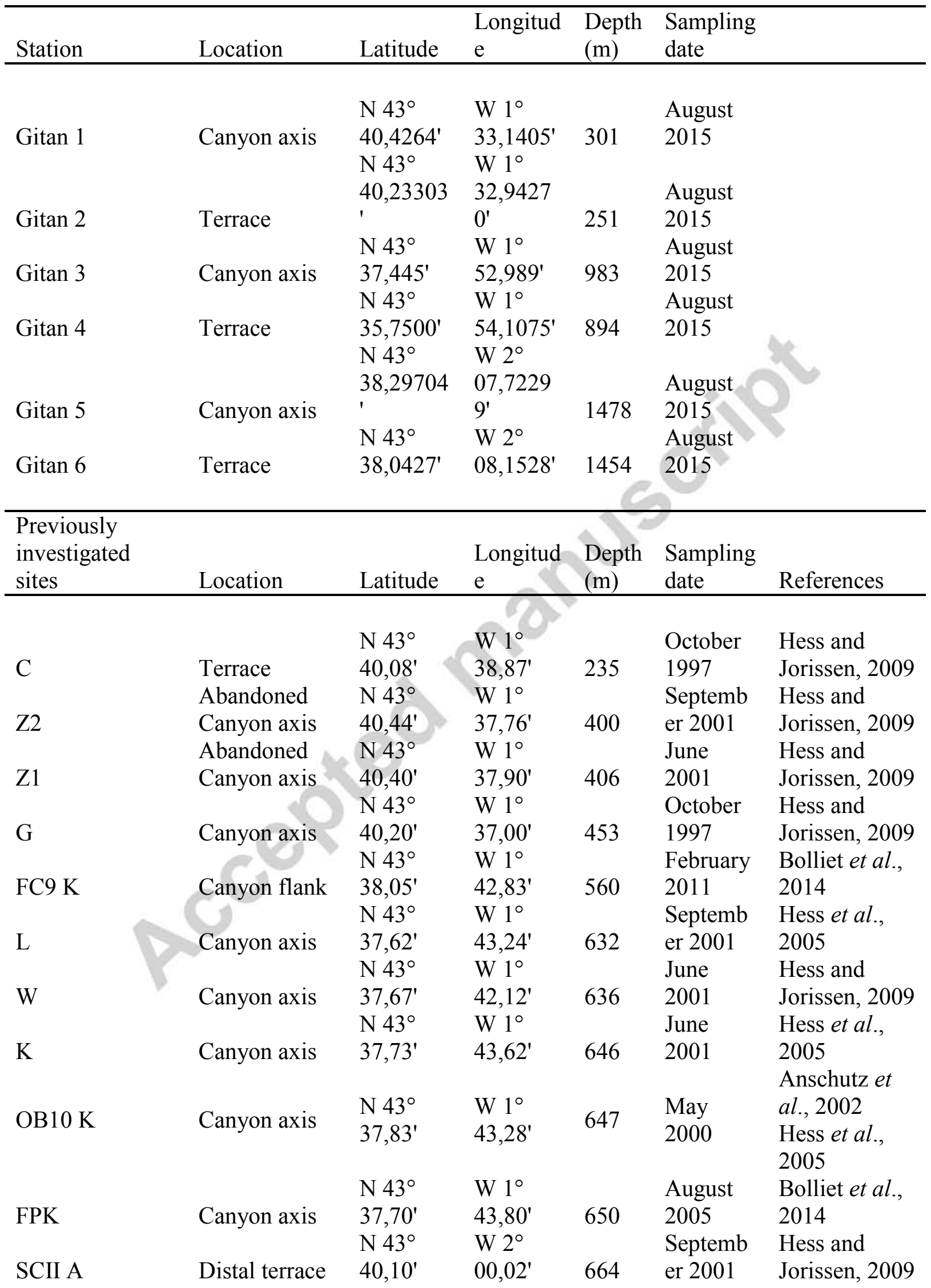




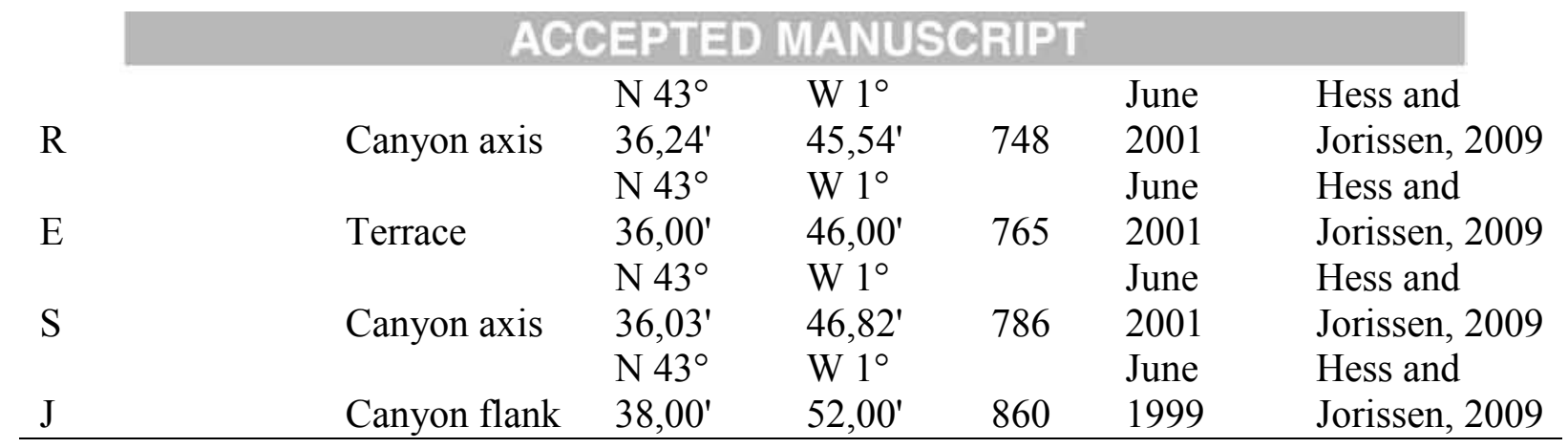

Table 2 - Standing stocks and biodiversity of living (stained) foraminiferal faunas ( $>150 \mu \mathrm{m})$ and qualitative observations (main species) of the 63-150 $\mu \mathrm{m}$ size fraction $(0-1 \mathrm{~cm})$ for the 6 stations in the Capbreton canyon area.

\begin{tabular}{|c|c|c|c|c|c|c|c|}
\hline Stati & Depth & Locatio & $\begin{array}{l}\text { Standing } \\
\text { stocks }\end{array}$ & Species & $\begin{array}{l}\text { Shann } \\
\text { on }\end{array}$ & $\begin{array}{l}\text { Even } \\
\text { ness }\end{array}$ & $\begin{array}{l}\text { Qualitative observations } \\
\text { (main species) }\end{array}$ \\
\hline ons & $(\mathrm{m})$ & & $\begin{array}{l}(\text { per } 100 \\
\left.\mathrm{cm}^{2}\right)\end{array}$ & $\begin{array}{l}\text { Richnes } \\
\text { s (S) }\end{array}$ & $\begin{array}{l}\text { Index } \\
\left(\mathrm{H}^{\prime}\right)\end{array}$ & \multicolumn{2}{|c|}{$\begin{array}{l}\text { Index of the } 63-150 \mu \mathrm{m} \text { fraction } \\
(\mathrm{E}) \quad(0-1 \mathrm{~cm})\end{array}$} \\
\hline $\begin{array}{l}\text { Gita } \\
\text { n } 1\end{array}$ & 301 & $\begin{array}{l}\text { Canyon } \\
\text { axis }\end{array}$ & 6548 & 44 & 1.82 & 0.14 & $\begin{array}{l}\text { High number of Bolivina } \\
\text { subaenariensis }\end{array}$ \\
\hline Gita & & & & & & & High number of Bolivina \\
\hline n 2 & 251 & Terrace & 21490 & 36 & 0.95 & 0.07 & subaenariensis \\
\hline Gita & & Canyon & & & & & High number of Bolivina \\
\hline $\begin{array}{l}\text { n } 3 \\
\text { Gita }\end{array}$ & 983 & axis & 564 & 23 & 2.14 & 0.37 & $\begin{array}{l}\text { subaenariensis } \\
\text { Very few individuals }\end{array}$ \\
\hline n 4 & 894 & Terrace & 1046 & 47 & 2.77 & 0.34 & (Reophax scorpiurus) \\
\hline $\begin{array}{l}\text { Gita } \\
\text { n } 5 \\
\text { Gita }\end{array}$ & 1478 & $\begin{array}{l}\text { Canyon } \\
\text { axis }\end{array}$ & 242 & 13 & 1.66 & 0.41 & $\begin{array}{l}\text { Very few individuals }(R . \\
\text { dentaliniformis) }\end{array}$ \\
\hline n 6 & 1454 & Terrace & 1090 & 12 & 1.02 & 0.23 & Few Fursenkoina bradyi \\
\hline
\end{tabular}




\section{ACCEPTED MANUSCRIPT}

Table 3 - Lithology, number of dead individuals (per $100 \mathrm{~cm} 2$ ), contribution of the dead allochthonous (neritic) individuals (per $100 \mathrm{~cm} 2$ ) and main species observed in the living and dead faunas in both sediment level studied at each station from Capbreton canyon axis and terraces $(>150$ $\mu \mathrm{m}$ size-fraction). Species included in the allochthonous taxa are Elphidium spp., Planorbulina mediterranensis, Planorbulinella larvata, Cibicides lobatulus, Ammonia beccarii, Gavelinopsis transluscens, Rosalina spp., Hanzawaia boueana, Planulina ariminensis and Quinqueloculina sp.1.

\section{Canyon axis}

\section{Studied level}

Lithology

Number of dead individuals (per 100 $\mathrm{cm}^{-2}$ )

Number of dead allochthonous (neritic) ind. (per $100 \mathrm{~cm}^{-2}$ ) $\%$ of dead allochthonous (neritic) ind.

Main species in the living fauna $(>5 \%)$

Main species in the dead fauna ( $>5 \%$ )
Gitan 1 (301 m)

$$
2-3 \mathrm{~cm}
$$

9-10 cm

Very fine to coarse

Silts sands

3315

1878

$$
57
$$

Planorbulin
$a$
mediterran
ensis

29348

25547

87
Bulimina marginata

Gitan 3 (983 m)

Gitan 5 (1478 m)

$2-3 \mathrm{~cm} \quad 9-10 \mathrm{~cm}$

2-3 cm 9-10 cm

$\begin{array}{ll} & \text { Fine } \\ \text { Silts } & \text { sand }\end{array}$

Medium

Silts sands

349

349

3613

11

238

86

1989

3

91

25

55

25

71

Quinque

loculina

sp.1

Fursenk

oina

bradyi

Cassidu $\quad P$.

lina mediter

Fursen

Ammoni

Elphidium mediterra

spp.

nensis

Bolivina

subaenarie

nsis

Bolivina subaenariensis

carinata

Cibicide

ranensis

beccarii

Cibicide

$s$

lobatulu

$s$

Fursenkoina

bradyi

Bolivina

subaenariensis lobatulu

$s$

Fursenkoina bradyi

\section{Terraces}

\section{Studied level}

Lithology

Number of dead

individuals (per 100
Gitan 2 (251 m)

$2-3 \mathrm{~cm} \quad 9-10 \mathrm{~cm}$
Gitan 4 (894 m) Gitan 6 (1454 m)

$2-3 \mathrm{~cm} \quad 9-10 \mathrm{~cm} \quad 3-4 \mathrm{~cm} \quad 7-8 \mathrm{~cm}$

Very

fine

Silts Silts Silts Silts Silts sands

$\begin{array}{llllll}12331 & 11845 & 7094 & 12416 & 148 & 961\end{array}$


$\mathrm{cm}^{-2}$ )

Number of dead

allochthonous (neritic)

ind. (per $100 \mathrm{~cm}^{-2}$ )

$\%$ of dead

allochthonous (neritic)

ind.

Main species in the

dead fauna ( $>5 \%$ )

Main species in the

living fauna $(>5 \%)$
88

530

1967

3200

7

381

1

4

28

Cassidu

26

Cassidu

lina

Bolivina

lina

Bolivina

carinata

carinata

subaenarie

nsis

subaenari

Cibicide

Cibicide

ensis

lobat

$s$

$S$
lobatulu

$S$

$s$

Uvigerina

Bolivina subaenariensis mediterranea

Uvigerina

peregrina

Highlights

- Live benthic foraminifera were studied at 6 deep stations in the Capbreton Canyon.

- Benthic foraminifera were sampled along canyon axis and its adjacent terraces.

- The aim is to use foraminifera as bio-indicators of hydro-sedimentary processes. 